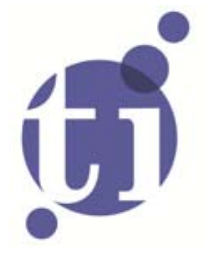

\title{
Cultural Heritage and the Attractiveness of Cities: \\ Evidence from Recreation Trips
}

Ruben van Loon

Tom Gosens

Jan Rouwendal

Faculty of Economics and Business Administration, VU University Amsterdam, and Tinbergen Institute, the Netherlands. 
Tinbergen Institute is the graduate school and research institute in economics of Erasmus University Rotterdam, the University of Amsterdam and VU University Amsterdam.

More TI discussion papers can be downloaded at http://www.tinbergen.nl

Tinbergen Institute has two locations:

Tinbergen Institute Amsterdam

Gustav Mahlerplein 117

1082 MS Amsterdam

The Netherlands

Tel.: +31(0)205251600

Tinbergen Institute Rotterdam

Burg. Oudlaan 50

3062 PA Rotterdam

The Netherlands

Tel.: +31(0)10 4088900

Fax: $+31(0) 104089031$

Duisenberg school of finance is a collaboration of the Dutch financial sector and universities, with the ambition to support innovative research and offer top quality academic education in core areas of finance.

DSF research papers can be downloaded at: http://www.dsf.nl/

Duisenberg school of finance

Gustav Mahlerplein 117

1082 MS Amsterdam

The Netherlands

Tel.: +31(0)20 5258579 


\title{
Cultural Heritage and the Attractiveness of Cities: Evidence from Recreation Trips
}

\author{
Ruben van Loon ${ }^{1}$ \\ Tom Gosens ${ }^{1}$ \\ Jan Rouwendal ${ }^{1,2}$ \\ 1 Department of Spatial Economics, VU University Amsterdam, De Boelelaan 1105, 108 HV \\ Amsterdam, The Netherlands. \\ 2 Tinbergen Institute, Gustav Mahlerplein 117, 1082 MS Amsterdam, The Netherlands
}

Key words: Cultural heritage, recreation, city marketing

JEL codes: C31, D12, R12, R22, L83.

\begin{abstract}
Many cities are trying to attract tourists by investing in urban amenities. Cultural heritage is an important example and substantial investments are needed to keep ancient inner cities and characteristic monumental buildings in good shape. The costs of these policies are usually clear, the benefits are often much more difficult to assess. This paper attempts to fill part of this gap by studying the destination choices of urban recreation trips that have urban recreation as the main travel motive. We estimate a discrete choice model for destination choice that takes into account the potential importance of unobserved characteristics. The model allows us to compute the marginal willingness to travel for destinations offering more cultural heritage, which we measure as the area of the inner city that has a protected status because of the cultural heritage that is present there.
\end{abstract}


Many agglomerations invest heavily in some urban amenities as they believe this will stimulate the local economy, which has also been endorsed by the urban economics literature (see e.g. Glaeser et al. 2001; Clark et al. 2002). Urban amenities provide job market opportunities to the local resident, and as employment grows the local economy is further stimulated. Public investments in amenities thus catalyze a chain of growth, and as the population density eventually increases when more and more jobs become available, the set of urban amenities is eventually also likely to expand with the provision of e.g. concert venues, museums, cinemas, and theatres. The local agglomeration's market however only continues to function if the consumer is willing to expend on the urban amenities of the agglomeration. The presence of workers close to the market makes it likely that the urban amenities will always generate some revenues, but many local authorities are seeking alternative ways to increase the revenue of the amenities in their agglomeration. One such method is to attract visitors from close-by agglomerations, but also other regions and even other countries. Vacations and day-trip recreation are namely very popular ways to spend leisure time. For instance, in the Netherlands the mean per-person per-year number of daytrips is 55, and given the per-trip per-person expenditures that amount to an average of 12.80 euro there is much to win for the local economy if an agglomeration manages to attract substantial groups of recreationists (Statistics Netherlands 2012). ${ }^{1}$

Local authorities deploy different kinds of strategies to attract recreationists, which include (but are not limited to) waterfront developments, cultural enhancement, and the preservation of historic buildings in the area of concern. The latter strategy has been receiving more and more attention since the 1990s. The concept itself has evolved as well. As heritage is a cultural construction its appreciation evolves over time (Peacock 1998), and over the years the scope of cultural heritage has been widened extensively. More and more types of artefacts are now considered for a heritage status (sometimes even intangible assets, see e.g. Rizzo and Throsby 2006), and more and more artefacts are officially selected - and thereby protected as a society's cultural heritage. ${ }^{2}$

As the number of heritage projects increase, the costs incurred are also likely to grow. The costs of protecting heritage are usually easy to compute, but its benefits are less clear as many heritage objects are non-rivalrous and non-excludable. As a result, the academic attention for cultural heritage has surged, and studies have been occupying themselves assessing the magnitude of the benefits that can be attributed to cultural heritage. There are many different

\footnotetext{
${ }^{1}$ Day-trips are defined as a trip for recreation, for which the consumer leaves the residence at least two hours, without an overnight stay involved (Statistics Netherlands 2013a).

${ }^{2}$ Noonan and Krupka (2010) provide an interesting analysis on which objects are more likely to be designated with some sort of cultural heritage status.
} 
ways to value an agglomeration's cultural heritage. A large stream of the literature has considered the value that recreationists attach to heritage objects when these are the consumer's goal of day-trips (see e.g. Bedate et al. 2004; Apostolakis and Jaffry 2005; Kim et al. 2007; Tuan and Navrud 2008). The heritage is in this case tangible and can be visited directly, sometimes even at the cost of an admission price. Naturally, the values of individual heritage sites differ, but Dziembowska and Funck (2000) conclude that heritage sites provide regions and agglomerations, also ones that are in principle poorly endowed with other amenities, with a strategy to develop economically.

Other ways in which heritage stimulates the local economy are less direct, but also substantial. Greffe (2004) for instance mentions the 'non-cultural' demand for cultural heritage, in which the heritage is the economic resource that stimulates the participation in other, non-cultural activities. Hence, the cultural heritage may also be a valuable asset for agglomerations that wish to attract visitors for trips when the cultural heritage is not the direct goal of the trip, or, in related terms, when the sites are not the prime beneficiaries of the trip. International tourism is a prominent example of such 'non-cultural' demand, and many local industries related to such tourism profit from the presence of cultural heritage. Cultural heritage is able to attract foreign visitors for longer periods of time, and heritage holidays have risen in popularity since the 1990s especially, at the cost of the traditional 3S (sunshine, sand, sea) holidays (Timothy and Boyd 2006). Alzua et al. (1998) and Yang et al. (2010) have provided valuations of the presence of heritage in tourists' holiday location choice.

If the presence of cultural heritage helps agglomerations in attracting visitors for holidays and heritage day-trips, then the premise that the outlook of the environment matters to the recreationist for regular, non-heritage day-trips is not improbable either (Bolt 1995). As mentioned previously, the average consumer undertakes a significant number of day-trips each year, with a generous amount of money spent, on average, during each trip. In only a small number of occasions recreationists target the cultural heritage as the goal of the trip (NBTC-Nipo 2007), which suggests that, if the presence of heritage matters for other, noncultural day-trips as well, the benefits for the local economy that can be attributed to cultural heritage are more substantial than usually suggested. This in turn could shed another light on the profitability of some heritage preservation projects, especially for smaller agglomerations that often cannot rely on high numbers of foreign tourists. A significant number of studies in the literature suggest that agglomerations with cultural heritage are indeed more likely to become the recreationist's regular day-trip destination (e.g. Jansen 1989; Jansen-Verbeke 1991; Law 2002; Litvin 2005; Murphy et al. 2010). However, most of these studies do not often do not provide empirical estimates of the value of cultural heritage to support their claims, although such information would be potentially very useful to assess the extent to which cultural heritage really matters . 
In this paper we aim to fill this gap by analysing the impact of cultural heritage on a trip type that fits in perfectly in-between holidays and heritage day-trips: urban recreation day-trips. We consider urban recreation to consist of trips for recreational shopping, to bars and taverns, and for eating out in restaurants, and our model considers the revealed choice behaviour of a representative set of consumers that resides and undertakes trips in the Netherlands, with for each consumer a countrywide municipality choice set. The context is suitable, as some Dutch agglomerations have significant amounts of cultural heritage dating back to the $17^{\text {th }}$ century within their borders. The analysis results in estimates of the recreationist's willingness-totravel for a larger presence of the cultural heritage. The paper also provides information on the amount of money spent by these visitors, and the combination of these two gives an idea to which extent an agglomeration should be able to gather additional revenues from extra visitors.

In this paper we rely on expert judgments for the indicator of cultural heritage. From an economic point of view, the appropriate conceptualization of cultural heritage is as capital (Rizzo and Throsby 2006). The Netherlands Institute for Cultural Heritage (abbreviated in Dutch as RCE) monitors two cultural heritage standards that consider capital goods. The first standard evaluates the combined quality of buildings and objects in specific areas, and if the experts judge the area is of value then a protected cityscape status, or, alternatively, protected historic district status, is granted. The protected cityscape status puts important restrictions on the possibility to change buildings, street patterns, and other objects, and achieving this status is the result of a long and complicated procedure. The status of protected cityscape simultaneously indicates the quality of the heritage and a strong desire to maintain and, in many cases, emphasize and develop this aspect, and many Dutch municipalities have sought after achieving this status in the last ten years. Using the protected cityscape area size as an indicator implies an emphasis on the real-estate component of this amenity, which is presumably the most relevant component in the creation of an attractive atmosphere for recreationists as it is the most visible component. We use the second cultural heritage standard, the national monument status, to check the robustness of our results. Monuments can be expected to have a similar effect, as these are generally also real estate. A third indicator for robustness analysis is the number of museums in each municipality. This indicator does not share the real estate component with the other indicators, but is expected to capture the cultural richness of the municipality.

Clearly, the scope of our study is limited in several respects. The study for instance focuses entirely on the use value of the cultural heritage, and on one specific type of users. The fact that we do not address the non-economic values or the existence, bequest, or option value of the cultural heritage should not be interpreted as if these other values do not matter. The sole reason for not investigating these is that this would take us too far afield. An in-depth study of 
the use value of heritage for this user type already contributes to a more complete picture of the value of cultural heritage.

The paper is organised as follows. In the next section we introduce the data sample and variables. Section 3 discusses the model and the econometric methodology. In Section 4 we report estimation results, while Section 5 concludes.

\section{Data}

\section{$2.1 \quad$ Recreation data sample}

Our paper uses the Continuous Leisure Survey (often abbreviated as CVTO), which is a twoyearly online survey on recreation behaviour ${ }^{3}$. Each week a representative sample of 350 respondents is requested to register home-based, out-of-home recreational activities that start and end on the same day, for a period of seven days. Only one member per household registers its participation in such activities, and for each trip the respondent lists information such as the visited municipality, expenditures, travel party, activity type, and start and end time. We will only consider respondents aged 16 and older, as these respondents generally have enough freedom and possibilities to travel wherever they would like to.

The database distinguishes no less than 113 recreation activities, which includes activities in the (broad) range of attending a professional football match to sitting in an outdoor café. Our application however focuses on urban recreation, which is the category of activities that typically take place in the centre of agglomerations such as eating out, bar and tavern visits, and recreational shopping. We include here those trips that endure at least 2 hours, which complies with the definition that Statistics Netherlands (2013a) uses for day-trips. Altogether, approximately $23 \%$ of the total number of trips belongs to the category urban recreation. Over $41 \%$ of the total sample of respondents undertakes at least one urban recreation trip during the week of observation, which underlines the significance that consumers attach to this type of activity. Table 1 provides descriptive statistics for the trip sample, both in terms of consumer characteristics as well as trip characteristics. The percentage of trips undertaken by non-native Dutch consumers is higher than their average presence in society $-12 \%$ here versus $8 \%$ in society according to Statistics Netherlands (2013b), which is in line with other studies that had already found differences in participation related to nativity (such as Shim and Gehrt 1996).

\footnotetext{
${ }^{3}$ The data is collected by NBTC (Dutch Bureau of Tourism and Conferences) and NIPO (Dutch Institute for Public Opinion - part of the TNS group).
} 
The average travelled distance requires some further elucidation. Of course, each respondent resides at a different location, and thus respondents need to travel dissimilar distances to arrive at the same alternative. We have computed the Euclidian distance between all pairs of municipalities in the Netherlands to account for this difference, and in our set of trips we observe an average distance travelled of approximately 16 kilometres for urban recreation ${ }^{4}$. The Euclidian distance suffices as proxy for travel distance in the Netherlands, as road and railway density is high all across the county and geological obstacles such as mountains are (almost) fully absent. The low average travel distance indicates that consumers perceive travel distance as a disutility, even for trips of potentially longer duration such as those in our sample.

Table 1: Descriptive statistics of the data sample

\begin{tabular}{|c|c|c|}
\hline Variable & Mean & S.D. \\
\hline Family0 dummy $=$ Single woman & 0.078 & 0.268 \\
\hline Family 1 dummy $=$ Single man & 0.091 & 0.289 \\
\hline Family 2 dummy $=$ Child(ren) aged below $12^{\mathrm{a}}$ & 0.135 & 0.341 \\
\hline Family 3 dummy $=$ Child(ren) aged 12 to 17 & 0.402 & 0.490 \\
\hline Family 4 dummy $=$ No children & 0.294 & 0.456 \\
\hline Age16-25 & 0.279 & 0.448 \\
\hline Age26-50 & 0.404 & 0.491 \\
\hline Age51-99 & 0.317 & 0.465 \\
\hline Non-native Dutch ancestry & 0.120 & 0.330 \\
\hline Household income $^{\mathrm{b}}$ & 43,957 & 28,671 \\
\hline Travel distance $^{c}$ & 15.770 & 27.930 \\
\hline Expenditure type $^{d}$ & Mean & S.D. \\
\hline Admission & 1.630 & 15.015 \\
\hline Food and beverages & 36.034 & 92.255 \\
\hline Shop products & 28.291 & 86.208 \\
\hline Other & 2.084 & 27.431 \\
\hline \multicolumn{3}{|l|}{$\mathrm{N}=7830$} \\
\hline \multicolumn{3}{|c|}{$\begin{array}{l}\text { a If the single status is not mentioned, then the respondent is part of a couple, eitl } \\
\text { children. Hence, Family4 dummy variable "No children" refers to respondents pa } \\
\text { either no children or children at an adult age. } \\
\text { b The gross annual income of the respondent's household (in euros). } \\
\text { c The travel distance is denoted in kilometres, here without the natural logarithm. } \\
\text { d The mean and standard deviation of the expenditures are per trip (in euros). }\end{array}$} \\
\hline
\end{tabular}

Although the model will not consider expenditures in the strictest sense, our data allows us to provide some general information with respect to the value these trips add to the economy. Table 1 shows that the average expenditure on food and beverages during urban recreation trips equals 36 euro, whereas the average expenditure on shop commodities amounts to 28 euro. Although these figures may seem modest given the fact that these involve trip totals and not per-person figures, if taken into account how many trips consumers undertake on a yearly

\footnotetext{
${ }^{4} \mathrm{We}$ assume that the distance travelled for trips that start and end in the same municipality equals 5 kilometers. Our assumption rests on the average distance between the midpoints of a municipality and its borders.
} 
basis the relevance of studying the value of cultural heritage for this type of trips is clear. If significant, authorities clearly have an incentive to prevent cultural heritage from depreciating. Insufficient maintenance may dilapidate existing heritage and lets its positive contribution to the attractiveness of municipalities disappear. The externalities brought to the economy may then also decrease, which has all kinds of multiplier effects in the rest of the agglomeration's, or even the region's, economy.

\subsection{Destination characteristics}

The sample data do not inform us about the characteristics of the alternatives in the choice set. We have therefore assembled information on the municipality characteristics that are deemed relevant using various other resources. Of course, the cultural heritage is the variable that we are mainly interested in, and we take use of data provided by the Netherlands Institute for Cultural Heritage (RCE 2012). Their database counts 61,172 national monuments and 459 protected cityscape areas.

The size of the area that has been awarded the status of protected cityscape in each municipality will be our main indicator. Municipalities can file an application to get parts of their territory assigned with the status of protected cityscape. The application is the start of a time-consuming procedure that may end with the protected status being granted. If granted, the municipality is obligated to take measures that preserve the typical character of the designated area, and the municipality receives some funding from the national government to do so. The procedure has been completed for areas dating back to 1850 or earlier, while applications for the period 1850-1940 are currently under consideration. The fact that the period until 1850 has been covered is relevant for this application, as many Dutch agglomerations date back to the $17^{\text {th }}$ century, and some of these agglomerations still have historical inner-cities. The analysis includes all areas that have been given the status of protected cityscape before the year 2008 .

The robustness of the estimates will be tested with two other indicators for cultural heritage, namely the number of national monuments per municipality (also provided by RCE) and the number of museums per municipality. The application for national monument status is also evaluated by the RCE. There is a wide range of objects that is listed as monument, such as dwellings, archaeological sites, and other historical buildings. The latter indicator (museums) is taken from the ABF Housing Monitor (2008). Rouwendal and Boter (2009) have suggested that museums quite often provide insight into the history of the agglomeration, and these museums are thus expected to indicate the cultural-historical richness of the agglomeration. 
The model will also have an indicator that represents the size of the agglomeration centre, which other studies have found to be an important, if not the most important, determinant of a consumer's destination choice (see e.g. Eppli and Shilling 1996; Oppewal et al. 1997; Teller et al. 2008). We have the number of shops and number of catering facilities per municipality at our disposal (also taken from the aforementioned ABF Housing Monitor), but the correlation between these two indicators is almost perfect, as Table 2 shows. Therefore, the model will only consider one variable, more specifically the number of catering facilities. The estimated coefficient should therefore be interpreted as referring to the combined effect of catering and shops on the recreationist's destination choice. Table 2 also shows the correlation between the three cultural heritage indicators and the two size variables, which is considerable. Moreover, the correlation between the heritage indicators themselves is in the range 0.5-0.9. Section 3 will discuss what measures we take in our model to deal with the correlation between these explanatory variables.

Table 2: Correlation matrix of the independent variables

\begin{tabular}{l|ccccc}
\hline & $\begin{array}{c}\text { Protected } \\
\text { cityscape } \\
\text { area size }\end{array}$ & $\begin{array}{c}\text { National } \\
\text { monuments }\end{array}$ & Museums & Shops & $\begin{array}{c}\text { Catering } \\
\text { facilities }\end{array}$ \\
\hline Protected cityscape area size & 1 & & & & \\
National monuments & 0.583 & 1 & & & \\
Museums & 0.613 & 0.831 & 1 & & \\
Shops & 0.645 & 0.783 & 0.900 & 1 & \\
Catering facilities & 0.649 & 0.848 & 0.919 & 0.984 & 1 \\
\hline
\end{tabular}

Although we expect these characteristics to capture already quite some variation in consumer behaviour, unobserved characteristics are very likely to create correlation in the unobserved portions of utility. Therefore, instead of considering each destination as a unique alternative, we test the aggregation of alternatives into distinct nests. A common grouping of Dutch municipalities is into tourist regions, of which Statistics Netherlands identifies seventeen relatively homogeneous units. We incorporate these into our analysis with some minor changes, as we disaggregate the four largest cities of the country (Amsterdam, Rotterdam, The Hague, and Utrecht) into separate tourist regions (instead of one region), and split the region 'Rest of the Netherlands' into a northern and western part. Municipalities in a given region possess to considerable extent similar amenities. ${ }^{5}$ The inclusion of dummies for these regions enables us to control for unobserved characteristics that are common to the regions. Figure 1 gives a map of the tourist regions, while Table A.1 in Appendix A provides some characteristics of the tourist regions. The table shows the dominant position of the four large cities in terms of the number of museums, monuments, the size of the protected cityscape area,

\footnotetext{
${ }^{5}$ This corresponds mostly to the dominant aspect of the region, such as beaches, hills, and/or lakes.
} 
and the number of catering facilities and shops. Table A.1 also shows, in the first column, the number of trips in the data sample to each tourist region. The sample data set includes trips to every tourist region, but some regions are clearly more popular for this particular trip type than others.

Before we proceed to the discussion of the model, a few words must be said about the omission of prices from our model. We were unable to construct a municipality-specific price index for the commodities relevant for urban recreation. Recreation expenditures cannot be regarded as price information, because information on the commodities bought, and foremost on the obliged nature of these, is missing. We therefore estimate the model without a price variable. A consequence is that we cannot determine the trade-off between the price of a recreation destination and the presence of cultural heritage in the usual way. However, we can instead investigate the trade-off between the distance that recreationists are willing to travel and the presence of cultural heritage. That is, we can determine the extra distance that a recreationist is willing to make in order to to visit a location where more cultural heritage is present. This gives us an alternative welfare indicator that is also intuitively plausible. ${ }^{6}$

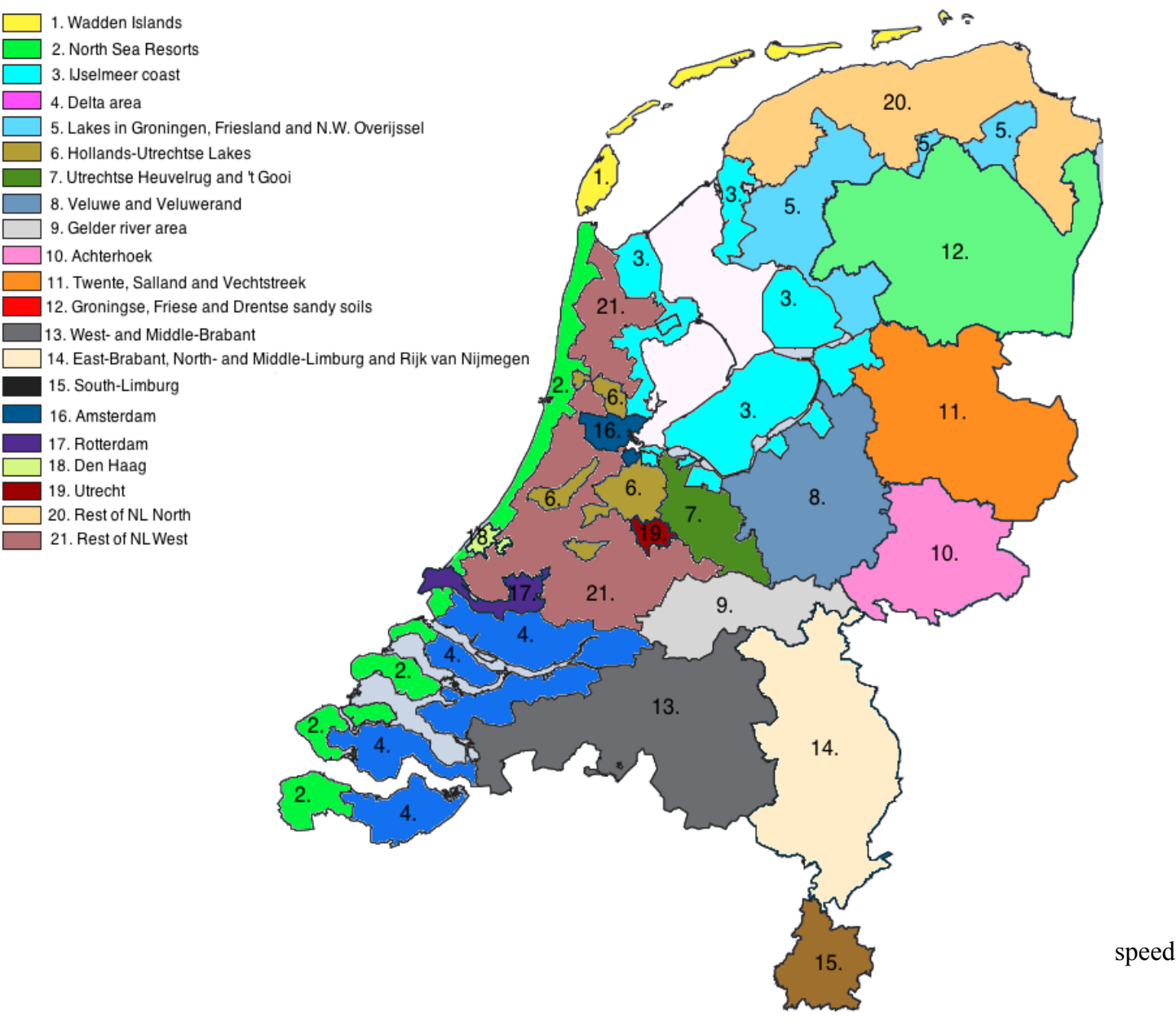

Figure 1: Tourist regions in the Netherlands 
The basic idea of the model is that the experience of having cultural heritage around adds significantly to the consumer's utility during urban recreation trips. This holds for activities such as recreational shopping, but perhaps even more for eating out for recreation, for which it is not only the meal that matters. The whole experience, including the environment in which restaurant is located, may add value to the trip. Jansen (1989) already stated, in a qualitative study based on the city of Amsterdam, that the way items are displayed is important; this holds also for cafés, tearooms and restaurants.

\subsection{A two-step procedure}

Since the seminal work of McFadden $(1973,1978$, 1981) discrete choice models have been often used in applied economic analysis, Ben-Akiva and Lerman (1985) and Train (2009) provide a detailed discussion of the interpretation of discrete choice models as the outcome of utility-maximizing choices, and their application. We estimate the model in two steps to take into account the probable presence of the unobserved destination characteristics. The first step is a nested logit model and includes alternative-specific constants for all municipalities, with the nesting based on the tourist region classification of Statistics Netherlands as discussed in the previous section. The other explanatory variables are constructed in such a way that the alternative-specific constants can be interpreted as the utility attached to the municipality by the average respondent, as will be discussed in detail below. In the second step the alternative-specific constants are further analysed using linear regression techniques.

The two-step procedure was introduced by Berry (1994) and Berry et al. (1995) to solve some issues in the use of discrete choice models in industrial organisation. In a more recent contribution Murdock (2006) stressed its importance for recreation destination choice models. A major advantage of the two-step procedure is that a researcher is able to deal with endogeneity issues in the context of discrete choice models, which was problematic in the literature to that date.

\subsection{The nested logit model}

We assume that a consumer maximizes his/her utility with the choice of some destination for an urban recreation trip. The total utility of a choice alternative is the sum of a deterministic and a stochastic part:

$$
U_{n i}=V_{n i}+\varepsilon_{n i}
$$


where $V_{n i}$ is the deterministic part of the utility $U_{n i}$ of alternative (destination) $i$ for individual $n$, and $\varepsilon_{n i}$ is the random part of utility that represents the idiosyncratic tastes of an individual for a particular destination.

The deterministic part of utility, $V_{n i}$ is a linear function of the site characteristics $H_{i}$ :

$$
V_{n i}=\sum_{j=1}^{J} \beta_{n j} H_{j i}+\gamma_{n i} \ln \left(D_{n i}\right)+\xi_{i}
$$

The number of relevant site characteristics is $J$, and $H_{j i}$ denotes the value of the $j$-th characteristic for destination $i . H_{i}$ is the matrix of all characteristics of destination $i$. One of these characteristics is the indicator of cultural heritage. $D_{n i}$ measures travel distance from a consumer's residence to the alternatives in the choice set. The final term, $\xi_{i}$, represents the unobserved characteristics of destination $i$. Although this variable is unobserved, it plays an important role in the analysis.

Note that the coefficients $\beta$ and $\gamma$ are $n$-specific, and thus differ among consumers. We specify these coefficients further by linking them to tourist characteristics:

$$
\begin{aligned}
& \beta_{n j}=\beta_{0 j}+\sum_{m=1}^{M} \beta_{m j}\left(Z_{m n}-\bar{Z}_{m}\right) \\
& \gamma_{n i}=\gamma_{0 i}+\sum_{m=1}^{M} \gamma_{m i}\left(Z_{m n}-\bar{Z}_{m}\right)
\end{aligned}
$$

where $M$ is the number of household characteristics, $Z_{m n}$ denotes the value of characteristic $m$ for consumer $n$, and $\overline{\bar{Z}}_{m}$ the average value of characteristic $m$ in the population. Hence, $\beta_{0 j}$ gives the average impact of characteristic $j$ on a consumer, while the $\beta_{m j}$ indicates how household characteristics affect this valuation. And $\gamma_{0 i}$ gives the average impact of the distance to a particular destination $i$, while $\gamma_{m i}$ indicates how household characteristics affect this value of distance.

The introduction of heterogeneity among respondents in the model through household characteristics is important because it implies that, even if we use multinomial logit, the IIA property is not present at the aggregate level. Substitution between alternatives is therefore not solely determined by our assumptions with respect to the random part of the utility function (the $\varepsilon_{n i}$ terms), but also by the coefficients to be estimated. ${ }^{7}$ The substitution of (3) into (2), gives:

$$
\begin{aligned}
V_{n i}= & \sum_{j=1}^{J}\left(\beta_{0 j}+\sum_{m=1}^{M} \beta_{m j}\left(Z_{m n}-\bar{Z}_{m}\right)\right) H_{j i} \\
& +\left(\gamma_{0 i}+\sum_{m=1}^{M} \gamma_{m i}\left(Z_{m n}-\bar{Z}_{m}\right)\right) \ln \left(D_{n i}\right)+\xi_{i}
\end{aligned}
$$

and we rewrite this as:

\footnotetext{
${ }^{7}$ The argument is similar as in the mixed logit model. Indeed, substitution of (3) in (2) and of the result in (1) leads to an equation that is analogous to the error components formulation of the mixed logit model. For a discussion of mixed logit see Train (2009), and for further discussion of specification (3) of the coefficients $\beta$, see Bayer et al. (2004) and Van Duijn and Rouwendal (2013).
} 


$$
\begin{aligned}
V_{n i}= & \delta_{i}+\sum_{j=1}^{J}\left(\sum_{m=1}^{M} \beta_{m j}\left(Z_{m n}-\bar{Z}_{m}\right)\right) H_{j i} \\
& +\left(\gamma_{0 i}+\sum_{m=1}^{M} \gamma_{m i}\left(Z_{m n}-\bar{Z}_{m}\right)\right) \ln \left(D_{n i}\right)
\end{aligned}
$$

with $\delta_{i}=\sum_{j=1}^{J} \beta_{0 j} H_{j i}+\xi_{i}$. The new variable $\delta_{i}$ thus gives the part of deterministic utility that is common to all consumers. This part includes the unobserved term $\xi_{i}$, to which we return below. For the moment, we note that we can interpret (6) as a utility function with an alternative specific constant $\left(\delta_{i}\right)$ that can be estimated in the conventional way.

The specification of the discrete choice model is completed by determining the joint distribution of the additive random terms $\varepsilon_{n i}$. As noted, we choose the GEV distribution that results in a nested logit model that has the tourist regions discussed above as nests. Denoting the set of destinations belonging to nest $k$ as $B_{k}$, the probability that consumer $n$ chooses alternative $i \in B_{k}$ is:

$$
P_{n i}=\frac{e^{V_{n i} / \lambda_{k}}\left(\sum_{j \in B_{k}} e^{V_{n j} / \lambda_{k}}\right)^{\lambda_{k}-1}}{\sum_{j^{\prime}=1}^{K}\left(\sum_{j \in B_{l}} e^{V_{n j} / \lambda_{l}}\right)^{\lambda_{l}}}
$$

The parameters $\lambda_{k}$, which must lie in the interval $(0,1]$ for consistency of the model with utility maximization, measures the degree of independence in unobserved utility among the alternatives in nest $k$. A value of $\lambda_{k}$ close to 1 means less correlation between the $\varepsilon^{\prime}$ s in nest $k$ and when $\lambda_{k}=1$ for all $k$ the model collapses to multinomial logit. A small value of $\lambda_{k}$ indicates a strong correlation between the $\varepsilon$ 's in nest $k$, and therefore that actual choice behaviour differs significantly from what would be suggested by the MNL.

If we substitute (6) into (7), we can estimate the parameters $\delta_{i}, \beta_{m j}$ and $\lambda_{k}$ by maximizing the implied likelihood function, which is an ordinary discrete choice model. That is, we estimate the $\delta_{i}{ }^{\prime} \mathrm{s}$ as alternative specific constants and the estimated values include the $\xi_{i}$. However, this is not the end of the story, since this only reveals part of the impact of cultural heritage on recreation destination choice, viz. the impact of recreationist characteristics represented by the

$\beta_{m j}$ terms. The average impact of cultural heritage is absorbed in the $\delta_{i}$, and to make it explicit we need a second estimation step.

\subsection{Further analysis of the alternative-specific constants}

In the second step, we return to the original formulation of the utility function and write the alternative specific constants as:

$$
\delta_{i}=\sum_{j=1}^{J} \beta_{0 j} H_{j i}+\xi_{i}
$$


This equation is linear in the coefficients $\beta_{0 j}$, while the $\xi_{i}$ 's can now be interpreted as the error terms of the equation. ${ }^{8}$

There are two main endogeneity issues in the context of the current paper. First, policymakers in municipalities that are considered attractive for urban recreation may react by actively promoting monument status and protected cityscape status so as to fully exploit the potential of their city, and secondly, the number of shops and catering facilities may react in similar ways through the market mechanism. As a result, the size of the area with a protected cityscape status and the number of shops and catering facilities may react to the unobserved (by the researcher) heterogeneity term $\xi_{i}$, through the political and market process, and if this happens, correlation between these explanatory variables and the error term in (8) results. The estimation of (8) by OLS would hence be inappropriate. To address these issues, we use instruments and estimate (8) by an instrumental variables (two-stage least-squares) regression. We use the population size of the year 1830 as an instrument for the cultural heritage indicator and the current population size (of the year 2007) as an instrument for the number of catering facilities (and shops). We expect that the population size of 1830 is correlated with the presence of cultural heritage and the current population size with the numbers of shops and restaurants, and do not expect these two variables to be correlated with the error term in (8) which refers to unobserved heterogeneity in the average household's attractiveness of a municipality as a location for urban recreation. Past and present population size can hardly be imagined to have a direct impact on a city's attractiveness for urban recreation, but must be expected to be strongly correlated with the presence of cultural heritage and current shopping possibilities. Van Duijn and Rouwendal (2013) show that the cultural heritage and the associated amenities, such as shops and restaurants, are important for the residential location choice. This implies higher residential prices in agglomerations with a relatively large amount of cultural heritage but not necessarily that these agglomerations have more inhabitants, as the population size is determined by the housing stock in their model. In fact, Dutch spatial planning practices impact the location of new housing strongly and the correlation between residential prices and the new housing construction is negligible (Van Duijn and Rouwendal 2013). It is mainly for this reason that we do not expect considerations with respect to urban recreation to play a role in the determination of the population size of Dutch agglomerations.

\footnotetext{
${ }^{8}$ Note that the average impact of unobserved heterogeneity will be included in the constant term that we include in (6).
} 


\section{$4 \quad$ Results}

\subsection{The first-step model estimation results}

Table 3 presents the results of the first step of the estimation procedure. The coefficients indicate how households with specific characteristics differ in their preferences from the average household, whose preferences are captured by the alternative-specific constant and will be discussed in the next subsection. The coefficients in Table 3 thus refer to the interactions between site characteristics and the respondents' characteristics (the $\beta$ terms in (6)) and the distance parameter (the $\gamma$ terms in (6)). In addition to these variables we include an indicator for the weather situation, which combines information on the temperature and precipitation on the day of observation. The destination characteristics in the model are the area size of the protected cityscape per municipality, the number of bars, taverns, and restaurants (catering facilities), and the product of these variables.

Many of the estimated coefficients in Table 3 are not significantly different from zero. This indicates that deviations from the preferences of the average household are modest. We see that couples with older kids and consumers of the eldest age category have a significantly lower preference for the protected cityscape area size per se, and attach a larger value to the combination of a protected cityscape and the presence of catering facilities.

The parameter for travel distance (expressed as the Euclidean number of kilometres between origin and destination) is highly significant, and has the expected negative sign. The size of the coefficient indicates that the disutility attached to the travel distance is quite large, and hence recreationists prefer destinations relatively close to home. There are statistically significant cross-effects for families with children (of all ages) with a negative sign, which is plausible. Non-native Dutch respondents and those with a high household income attach a lower disutility to travel distances.

With respect to catering (and shopping) facilities, we find that that couples with teenage children have a lower than average preference for this amenity, whereas people under twentyfive prefer them more than the average respondent. Young consumers with relatively high incomes are thus especially attracted to the shops and restaurants of cities.

A graphical version of the alternative-specific constants (ASCs), which have been estimated

jointly with the parameters that are reported in Table 3, is presented in Appendix B. These coefficients will be further discussed in the next subsection. Appendix D reports the values of the parameters $\lambda_{k}$ that refer to the tourist regions in the nesting structure. As noted above, these parameters indicate the correlation between the idiosyncratic parts of the preferences of respondents for destinations in the same region. In 13 cases the nesting parameter was in the range of 0 and 1 , usually with statistical significance. Nested logit is therefore preferred over the standard multinomial logit model. 
Table 3: Estimation results of the nested-logit destination choice model, with "protected cityscape area size" as heritage indicator

\begin{tabular}{|c|c|c|c|c|c|c|c|c|}
\hline Main effect & Coefficient & S.E. & & & & & & \\
\hline Log of travel distance & $-2.361 * * *$ & 0.021 & & & & & & \\
\hline \multirow[t]{2}{*}{ Cross-effects } & \multicolumn{2}{|c|}{ Log of travel distance } & \multicolumn{2}{|c|}{ Number of catering facilities } & \multicolumn{2}{|c|}{ Protected cityscape area size } & \multicolumn{2}{|c|}{ Catering X Cityscape } \\
\hline & Coefficient & S.E. & Coefficient & S.E. & Coefficient & S.E. & Coefficient & S.E. \\
\hline Single man & -0.048 & 0.060 & -0.015 & 0.018 & -0.054 & 0.061 & 0.004 & 0.003 \\
\hline No children & -0.081 & 0.052 & -0.020 & 0.015 & -0.029 & 0.050 & 0.002 & 0.003 \\
\hline Child(ren) aged below 12 & $-0.268 * * *$ & 0.061 & -0.029 & 0.017 & -0.063 & 0.063 & 0.003 & 0.003 \\
\hline Child(ren) aged 12 to 17 & $-0.257 * * *$ & 0.051 & $-0.037 * *$ & 0.015 & $-0.144 * * *$ & 0.051 & $0.008 * * *$ & 0.003 \\
\hline Age26-50 & 0.047 & 0.034 & $-0.018 * *$ & 0.008 & -0.001 & 0.034 & 0.002 & 0.002 \\
\hline Age 51-99 & -0.008 & 0.040 & $-0.056 * * *$ & 0.010 & $-0.108 * * *$ & 0.038 & $0.009 * * *$ & 0.002 \\
\hline Non-native Dutch & $0.094 * *$ & 0.038 & 0.006 & 0.010 & 0.017 & 0.037 & -0.000 & 0.002 \\
\hline Household income & $0.012 * * *$ & 0.004 & 0.001 & 0.001 & 0.004 & 0.004 & -0.000 & 0.000 \\
\hline Weather & -0.027 & 0.018 & -0.002 & 0.004 & 0.002 & 0.017 & 0.001 & 0.001 \\
\hline
\end{tabular}

All coefficients are based on the sample of 7830 trips and the 403 municipalities that were revealed as destination. For the sake of brevity, we have not included the 402

alternative-specific constants, these are presented graphically in Figure A2. The estimates of the $\lambda_{k}$ parameter are given in Appendix D.

The reference to the first four respondent characteristics is "Single woman", and the reference to the age categories is "Age16-25". The variable "Household income" has been added to the model divided by 1,000 .

** Coefficient is statistically significant at the 0.05 level (2-tailed).

*** Coefficient is statistically significant at the 0.01 level (2-tailed)

The adjusted McFadden's pseudo R-squared equals 0.015. The log-likelihood equals -15848.607. 


\subsection{The second-step model estimation results}

The second step further analyses the alternative-specific constants $\left(\delta_{\mathrm{i}}\right)$ estimated in the nested logit model on the basis of the linear equation (8), which is now further specified as:

$$
\delta_{i}=\alpha+\beta_{1} C H_{i}+\beta_{2} C H_{i} C A T_{i}+\beta_{3} C A T_{i}+\sum_{r} \gamma_{r} T_{r i}+\xi
$$

In this equation $\mathrm{CH}_{i}$ refers to the area that has received the protected cityscape status in destination $i, C A T_{i}$ is the number of catering facilities, and $T_{r i}$ is a categorical variable indicating that destination $i$ is part of tourist region $r$. Table 4 shows the regression results of instrumental variables (2SLS) regression. The regressions are carried out with weights equal to the inverse of the standard error of the alternative-specific constants, to take into account heteroskedasticity related to difference in the standard errors of these variables. The intuition is that destinations whose utility for the average consumer could be estimated more precisely receive a larger weight in the regression (see, for instance, Greene 2011). Table E.1 in Appendix E shows the first-stage regression estimates for the instrumented variables.

The instrumental variables regression finds significant coefficients (with positive signs) for both the cultural heritage indicator (here, the area size of protected cityscape) and the number of catering facilities. The cross-effect between these two is however negative. The latter finding indicates that the experience of cultural heritage becomes less valuable if there are (too) many shops and restaurants in the same area, and, perhaps more importantly for this type of recreation, the other way around. ${ }^{9}$ It is worthwhile to note that our results are not driven by the large amount of cultural heritage in the capital Amsterdam, or by specific aspects of the other three largest agglomerations of the country, since we have introduced individual effects for these municipalities. ${ }^{10}$

\subsection{Robustness analysis}

The indicator that captures the amount of cultural heritage per municipality may be relatively coarse as the area of protected cityscape might be unable to reflect the full heterogeneity of this amenity. Hence, we have replicated the analysis with two other indicators for the extent of cultural heritage, namely the number of listed monuments and the number of museums per municipality. The results are predominantly reported Appendix C.

\footnotetext{
${ }^{9}$ The net-effect of the heritage variable cityscape on utility remains positive for $93 \%$ of the municipalities under study.

${ }^{10}$ That is, we have treated them as separate tourist regions, as was explained in Section 2.
} 
Table 4: Estimation results of the linear regression models, with "Protected cityscape area size" as heritage indicator

\begin{tabular}{|c|c|c|c|c|}
\hline & \multicolumn{2}{|c|}{$\begin{array}{l}\text { Ordinary least } \\
\text { squares regression }\end{array}$} & \multicolumn{2}{|c|}{$\begin{array}{c}\text { Instrumental } \\
\text { variables (2SLS) } \\
\text { regression }\end{array}$} \\
\hline & Coefficient & S.E. & Coefficient & S.E. \\
\hline Catering facilities $(C A T)$ & $0.790 * * *$ & 0.051 & $0.975 * * *$ & 0.080 \\
\hline Protected cityscape area size $(\mathrm{CH})$ & $0.461 * * *$ & 0.113 & $1.317 * * *$ & 0.308 \\
\hline Catering facilities $\mathrm{X}$ Protected cityscape area size $(\mathrm{CHCAT})$ & $-0.164 * * *$ & 0.038 & $-0.474 * * *$ & 0.074 \\
\hline (Constant) & -0.283 & 0.152 & -0.306 & 0.167 \\
\hline \multicolumn{5}{|l|}{ Tourist region dummies: } \\
\hline TR Wadden islands & $1.102 * *$ & 0.472 & 0.907 & 0.519 \\
\hline TR North Sea resorts & $-0.454 * *$ & 0.227 & $-0.785 * * *$ & 0.256 \\
\hline TR IJsselmeer coast & 0.217 & 0.216 & -0.090 & 0.246 \\
\hline TR Delta area & -0.023 & 0.207 & -0.347 & 0.241 \\
\hline TR Lakes in Groningen, Friesland and Noordwest-Overijssel & -0.522 & 0.271 & -0.328 & 0.298 \\
\hline TR Holland-Utrecht Lakes & $-1.155 * * *$ & 0.274 & $-1.259 * * *$ & 0.300 \\
\hline TR Utrechtse Heuvelrug and 't Gooi & 0.360 & 0.238 & 0.119 & 0.265 \\
\hline TR Veluwe and Veluwerand & $0.851 * * *$ & 0.231 & $0.714 * * *$ & 0.256 \\
\hline TR Gelderlands river area & $0.518 * *$ & 0.262 & 0.243 & 0.292 \\
\hline TR Achterhoek & $0.793 * * *$ & 0.251 & 0.510 & 0.280 \\
\hline TR Twente, Salland and Vechtstreek & $0.829 * * *$ & 0.219 & $0.637 * * *$ & 0.245 \\
\hline TR Sandy soils in Groningen, Friesland and Drenthe & 0.181 & 0.238 & -0.036 & 0.264 \\
\hline TR West- and Middle-Brabant & $0.715 * * *$ & 0.189 & $-0.577 * * *$ & 0.209 \\
\hline $\begin{array}{l}\text { TR East-Brabant, North- and Middle- Limburg and Rijk van } \\
\text { Nijmegen }\end{array}$ & $1.152 * * *$ & 0.194 & $1.003 * * *$ & 0.216 \\
\hline TR South-Limburg & -0.070 & 0.235 & -0.195 & 0.263 \\
\hline TR Amsterdam & 15.994 & 9.563 & $93.532 * * *$ & 18.90 \\
\hline TR Rotterdam & $-11.695 * * *$ & 1.425 & $-13.060 * * *$ & 1.591 \\
\hline TR Den Haag & $23.185 * * *$ & 9.271 & $87.971 * * *$ & 15.45 \\
\hline TR Utrecht & $-2.378 * * *$ & 1.122 & -0.909 & 0.968 \\
\hline TR Rest of NL West & $-0.497 * * *$ & 0.176 & $-0.660 * * *$ & 0.194 \\
\hline TR Rest of NL North & - & - & - & - \\
\hline Adjusted $\mathrm{R}^{2}$ & 0.635 & & 0.566 & \\
\hline Cragg-Donald Wald F-statistic & - & & 20.351 & \\
\hline \multicolumn{5}{|c|}{$\begin{array}{l}\text { All coefficients are based on the sample of } 7830 \text { trips and the } 403 \text { municipalities that were revealed as } \\
\text { destination. The first-stage estimation results of the instrumental variables regression are in Appendix E, } \\
\text { Table E. } 1 . \\
\text { ** The coefficient is statistically significant at the } 0.05 \text { level (2-tailed). } \\
* * * \text { The coefficient is statistically significant at the } 0.01 \text { level (2-tailed). }\end{array}$} \\
\hline
\end{tabular}

The first-step estimates of the previous section are mostly reproduced with the other indicators for cultural heritage. The travel distance coefficient and the cross-effects of the travel distance with the respondent characteristics are of course very much the same, because of the bias-free estimation of the travel distance parameter in the first step of the model. There seems to be some household-type heterogeneity with respect to the effect that the number of national monuments has on the consumer destination choice. All included households types 
(which are opposed to the omitted group of respondents that are member of a household with children older than 18 years) show lower than average preference for the presence of national monuments in the municipality of choice. The cross-effect of the number of catering facilities and national monuments yields coefficients of opposite signs for the households, suggesting that the respondents of these household types more than on average prefer destinations with both catering facilities and cultural heritage rather than just cultural heritage present.

The linear regressions are of most interest at this stage. The inclusion of the number of national monuments or museums instead of the protected cityscape area size does not lead to substantial changes in the results. The coefficients for catering facilities, cultural heritage, and their cross-effect are still statistically significant and of the same sign. Moreover, the difference between the OLS regression and the IV 2SLS regression is comparable across the three different specifications. It is safe to say that the results are robust with respect to these indicators for cultural heritage. Appendix E reports the first-stage OLS regression estimates for the specifications with the number of national monuments and museums as indicator for the level of cultural heritage in a municipality.

\subsection{The willingness-to-travel for cultural heritage}

To facilitate the interpretation of the estimation results, we have calculated the marginal willingness-to-travel for cultural heritage. This variable tells us how many additional kilometres a consumer is willing to travel for urban recreation to a destination with more cultural heritage. To understand the computation involved, recall that in our estimated model the utility $V$ attached to a particular destination is a function of the cultural heritage $\mathrm{CH}$ present there, the distance $D$ that has to be travelled to reach it, and other variables. Suppressing the latter, we can write this in symbols as: $V=V(C H, D)$. Now consider the change in utility that results from small changes in cultural heritage and travel distance. Using the symbol $d$ for small changes, we write:

$$
d V=\frac{\partial V}{\partial C H} d C H+\frac{\partial V}{\partial D} d D
$$

To measure the trade-off that the consumer is willing to make between cultural heritage and distance, we compute the change in travel distance that compensates the consumer for a change in cultural heritage. If the consumer is compensated utility remains constant $(d V=0)$, and we can rewrite the equation as:

$$
d D=\left(-\frac{\partial V}{\partial C H} / \frac{\partial V}{\partial D}\right) d C H .
$$

The expression in brackets gives the number of additional kilometres the consumer is willing to travel for a unit increase in cultural heritage. To compute this marginal willingness-to- 
travel from our estimated model, we return to the utility function (2) in which (3) and (4) have been substituted and suppress the terms that do not contain either $C H_{i}$ or $\ln D_{n i}:{ }^{11}$

$$
\begin{gathered}
V_{n i}=\cdots+\left(\beta_{0, C H}+\sum_{m=1}^{M} \beta_{m, C H}\left(Z_{m n}-\bar{Z}_{m}\right)\right) C H_{i} \\
+\left(\beta_{0, C H C A T}+\sum_{m=1}^{M} \beta_{m, C H C A T}\left(Z_{m n}-\bar{Z}_{m}\right)\right) C H_{i} S_{i} \\
+\left(\gamma_{0 i}+\sum_{m=1}^{M} \gamma_{m i}\left(Z_{m n}-\bar{Z}_{m}\right)\right) \ln D_{n i}
\end{gathered}
$$

In this equation $Z_{j}$ denotes the value of the $j$-th family characteristic of a consumer; $\overline{\bar{Z}}_{j}$ the average of this characteristic in the population, and $S$ the number of catering facilities (or shops). The two partial derivatives in (11) can now be computed as:

$$
\begin{aligned}
\frac{\partial V_{n i}}{\partial C H}= & \left(\beta_{0, C H}+\sum_{m=1}^{M} \beta_{m, C H}\left(Z_{m n}-\bar{Z}_{m}\right)\right)+ \\
& \left(\beta_{0, C H C A T}+\sum_{m=1}^{M} \beta_{m, C H C A T}\left(Z_{m n}-\bar{Z}_{m}\right)\right) S_{i} \\
\frac{\partial V_{n i}}{\partial D}= & \frac{1}{D_{n i}}\left(\gamma_{0 i}+\sum_{m=1}^{M} \gamma_{m i}\left(Z_{m n}-\bar{Z}_{m}\right)\right)
\end{aligned}
$$

Using these results, we can compute the willingness-to-travel for consumers with any combination of characteristics $Z_{1} \ldots Z_{M}$. The computation for the average consumer is simplest:

$$
-\frac{\partial V}{\partial C H} / \frac{\partial V}{\partial D}=-D_{m i} \frac{\beta_{0, C H}+\beta_{0, C H C A T} S_{i}}{\gamma_{0 i}}
$$

Using sample means for the travel distance (15.770 kilometres) and the number of catering facilities (1.132, which is in thousands as the variable in the base model), we find:

$$
-D_{m i} \frac{\beta_{0, C H}+\beta_{0, C H S} S_{i}}{\gamma_{0 i}}=-15.770 * \frac{1.317+(-0.474 * 1.132)}{-2.361}=5.213
$$

That is: the marginal willingness-to-travel is 5.213 kilometres per extra square kilometre of area with a protected cityscape status, for a recreationist with an average travel distance of 15.770 kilometres. Table 5 summarises the willingness-to-travel for an extra 250 square meters of area with a protected cityscape status for the statistically significant consumer characteristics. ${ }^{12}$ We evaluate here the increase of 0.250 square kilometres, as the current average protected cityscape area size is 0.240 square kilometres per municipality. ${ }^{13}$ Hence, the projected increase would imply a doubling, on average, of the area with a heritage status.

\footnotetext{
${ }^{11}$ We start from the first line of (5), and, slightly abusing the notation, we use $j=C H, C H C A T$ for the characteristics cultural heritage and cultural heritage times the number of catering facilities.

${ }^{12}$ The statistically insignificant coefficients of the first step of the nested logit model (in Table 3 ) have been set to 0 . As a result, the marginal willingness-to-pay for recreationists who do not have children in the household aged 12 to 17 or are of age 51 to 99 is that of the size of the average recreationist, 1.303 kilometres.

${ }^{13}$ The average area of protected cityscape for municipalities that have such an area is $1.09 \mathrm{~km}^{2}$.
} 
Table 5: The marginal willingness-to-travel (WTT) for extra areas with a protected cityscape status

\begin{tabular}{l|c}
\hline Type of respondent & Marginal \\
\hline Average recreationist & 1.303 \\
Child(ren) aged 12 to 17 & 1.099 \\
Age51-99 & 1.196 \\
\hline All marginal WTTs are denoted in kilometres. & \\
\hline
\end{tabular}

The estimates in Table 5 indicate that a respondent is willing to travel 1.303 additional kilometres for an additional 0.250 square kilometres of the area protected with a cityscape status. The marginal willingness-to-travel is slightly lower for recreationists aged over 50 and recreationists part of a couple with a child or children aged 12 to 17, which is of course consistent with their reported lower than average preference for cultural heritage (see Table 3). The marginal WTT estimates may seem quite modest at first sight. These numbers, for instance, indicate that the average recreationist is only willing to increase his or her travel less than $10 \%$ of the distance he or she is now travelling, whereas the protected area would have to be doubled (at least, it is a doubling in the average municipality). Nevertheless, the estimates show that cultural heritage has a significant impact on destination choice of daytrips. And it should be noticed that if an historical district is present, its size is often larger than 0.25 $\mathrm{km}^{2}$. Moreover, the number of daytrips undertaken is so large that even modest changes in destination choice have a non-negligible impact on the revenues of local shops and catering facilities. Our estimates therefore clearly suggest that cultural heritage is important for making a municipality attractive visitors, even if their main travel purpose is not specifically related to heritage.

Sometimes modest changes are also just enough to convince new recreationists. A striking example for the Netherlands lies perhaps in the urban growth centre Houten, which is situated approximately 17 kilometres away from major agglomeration Utrecht, thus slightly further away than the current average travelled distance. Although Houten is becoming increasingly attractive in terms of shopping, restaurants, and bars, and it even has some cultural heritage in the agglomeration centre, the larger presence of well-preserved cultural heritage in Utrecht could just lure the recreationist residing in Houten a couple of times more away to visit Utrecht for urban recreation purposes. As almost 50,000 people reside in Houten this agglomeration has quite some potential, which the local Utrecht restaurants, bars, and shops are of course happy to cover. If one takes into account the average expenditure on commodities during such trips, then it seems clear that there is much to win for some local markets, and great wins may actually be achievable even though behavioural changes are only limited in some sense. 


\section{Conclusions}

Although there is general recognition that the presence of cultural heritage contributes to the attractiveness of cities, there is not much systematic evidence on the heritage's potential for bringing visitors to the city for recreation purposes, at least not when the heritage is directly involved in the recreation trip. Such knowledge is helpful for the evaluation of new cultural heritage preservation plans, which are increasing in number and scope. This paper has contributed to the literature on this issue by analysing the effect of cultural heritage on the recreationist's destination choice for urban recreation trips with the help of a representative recreation survey of the Netherlands. Urban recreation, for which recreational shopping trips, bar and tavern visits, and eating out trips in restaurants are considered, is a recreational activity type that yields high participation rates, but also generates considerable expenditures, and the combination of these two factors underlines its importance for the functioning of local markets.

The model has the cultural heritage included with the municipal size of the area with a protected cityscape status, whose credentials can be compared with the historic district status in the United States. The regressions confirm that the main effect of the cultural heritage on the attractiveness of an agglomeration, for urban recreation purposes, is positive. Dining and shopping thus become a more enjoyable experience when cultural heritage is present at or near the recreation site. An agglomeration is also more likely to become visited if there are more catering facilities around. The model also shows that too much of both can work counterproductively, as the cross-effect between the extent of cultural heritage and catering facilities is negative, and the estimation results are robust when taking other indicators of cultural heritage into consideration. With the help of the model estimates, this paper has computed a marginal willingness-to-travel figure for an increase in the area protected with a cityscape status, and this estimate lets us conclude that the average recreationist is willing to travel approximately 1.3 kilometres further for a protected cityscape area size increase of 250 square meters. This increase is modest but non-negligible, and under the right circumstances (e.g. some large, low-on-heritage agglomerations nearby) the associated revenues for an agglomeration with cultural heritage can be impressive given the high amount of per-trip expenditures as well as the total number of urban recreation trips.

There are possibly also multiplier effects through the cultural heritage, which have not been touched upon here. The recreationists that are attracted to an agglomeration (in the first place) through its cultural heritage will, as a result of their expenditures, contribute to the number 
and probably also to the diversity of the shopping and catering facilities. ${ }^{14}$ This is an important issue for further investigation, which also holds for our finding of the negative cross-effect of cultural heritage and catering facilities. Moreover, the indicator for the presence of cultural heritage does, admittedly, not carry so much detail. More information on the quality and diversity of cultural heritage objects may improve our understanding of its impact on urban recreation day-trips. We expect that reputation effects of a heritage object are positive for the heritage's potential to hand the local economy external benefits, as Brau et al. (2003) have also suggested.

The fact that only the economic value, and in this case specifically the use value of the heritage, has been studied does not imply there are no other (e.g. historical, ethnological, and/or anthropological) values relevant in the evaluation of new heritage preservation projects. The scope of this study has been quite narrow on purpose, but the study is still an addition to the body of literature that has for instance already shown the positive effect of cultural heritage in attracting visitors for vacations and heritage day-trips, for other types of trips such as nature-based recreation (Gosens et al. 2014), and for the consumer's residential location choice.

\section{Acknowledgements}

We would like to thank Henri de Groot and Mark van Duijn for their insightful comments. We thank RCE, ABF Research and Statistics Netherlands for providing us with excellent data. We would also like to thank the members of the Department of Spatial Economics for helpful comments during discussions. R.v.L. gratefully acknowledges CLUE, NICIS and VU University for their financial support.

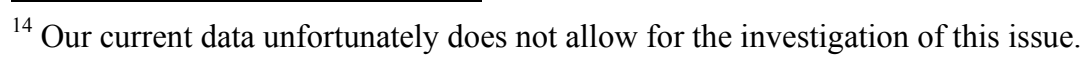




\section{References}

ABF Research (2008). ABF Research Housing Monitor. Delft: ABF Research BV.

Alzua, A., O’Leary, J. T., \& Morrison, A. (1998). Cultural and heritage tourism. Journal of Tourism Studies, 9(2), 2-13.

Apostolakis, A., \& Jaffry, S. (2005). A choice modelling application for Greek heritage attractions. Journal of Travel Research, 43(3), 309-318.

Bayer, P., McMillan, R., \& Rueben, K. (2004). An equilibrium model of sorting in an urban housing market. NBER Working Paper No. 10865.

Bedate, A., Herrero, L.C., Sanz, A. (2004). Economic valuation of the cultural heritage: application to four case studies in Spain. Journal of Cultural Heritage, 5(1), 101-111.

Ben-Akiva, M., \& Lerman, S. R. (1985). Discrete choice analysis: Theory and application to travel demand. Cambridge, MA: MIT Press.

Berry, S. (1994). Estimating discrete-choice models of product differentiation. RAND Journal Economics, 25(2), 242-262.

Berry, S., Levinsohn, J., \& Pakes, A. (1995). Automobile prices in market equilibrium. Econometrica, 63(4), 841-890.

Bolt, E.J. (1995). Produktvorming in de detailhandel. Nuth: Rosbeek BV.

Brau, R., Lanza, A., \& Pigliaru, F. (2003). How fast are the tourism countries growing? The cross-country evidence. FEEM Working Paper No. 85.

Clark, T.N., Lloyd, R., Wong, K.K., \& Jain, P. (2002). Amenities drive urban growth. Journal of Urban Affairs, 24(5): 493-515.

Duijn, M. van, \& Rouwendal, J. (2013). Cultural heritage and the location choice of Dutch households in a residential sorting model. Journal of Economic Geography, 13(3), 473-500.

Dziembowska-Kowalska, J., \& Funck, R. H. (2000). Cultural activities as a location factor in European competition between regions: concepts and some evidence. The Annals of Regional Science, 34(1), 1-12.

Eppli, M. J., \& Shilling, J. D. (1996). Changing economic perspectives on the theory of retail location. In J. Benjamin (ed.), Megatrends in retail real estate (pp. 65-80). Dordrecht: Kluwer Academic Publishers.

Glaeser, E. L., Kolko, J. \& Saiz, A. (2001). Consumer city. Journal of Economic Geography, $1(1), 27-50$

Gosens, T. C. A. P., Loon, R. R. van, \& Rouwendal, J. (2014). Assessing the use value of the non-urban landscape from an investigation of destination choice for nature-based recreation trips. Working paper.

Greene, W. (2011). Econometric analysis. Upper Saddle River, NJ: Prentice Hall. 
Greffe, X. (2004). Is heritage an asset or a liability? Journal of Cultural Heritage, 5(3), 301309.

Jansen, A. C. M. (1989). Funshopping as a geographical notion, or: the attraction of the inner city of Amsterdam as a shopping area. Tijdschrift voor economische en sociale geografie, 80(3), 171-183.

Jansen-Verbeke, M. (1991). Leisure shopping: a magic concept for the tourism industry? Tourism Management, 12(1), 9-14.

Kim, S. S., Wong, K. K. F., \& Cho, M. (2007). Assessing the economic value of a World Heritage site and willingness-to-pay determinants: a case of Changdeok Palace. Tourism Management, 28(1), 317-322.

Law, C. M. (2002). Urban tourism, the visitor economy and the growth of large cities. New York, NY: Continuum.

Litvin, S. W. (2005). Streetscape improvements in an historic tourist city: a second visit to King Street, Charleston, South Carolina. Tourism Management, 26(3), 421-429.

Loon, R. R. van, \& Rouwendal, J. (2013). Cultural heritage and domestic tourism in the Netherlands. Working Paper.

McFadden, D. L. (1973). Conditional logit analysis for Qualitative Choice Behavior, In P. Zarembka (ed.). Frontiers in econometrics (pp. 105-142). New York, NY: Academic Press.

McFadden, D. L. (1978). Modelling the choice of residential location. In A. Karlqvist, L. Lundqvist, F. Snickars, \& J. W.Weibull (eds.). Spatial interaction theory and planning models (pp. 75-96). Amsterdam: Elsevier.

McFadden, D. L. (1981). Econometric models of probabilistic choice, In C .F. Manski, \& D. L. McFadden (eds.). Structural analysis of discrete data with econometric applications (pp. 198-272). Cambridge, MA: MIT Press.

Murdock, J. (2006). Handling unobserved site characteristics in random utility models of recreation demand. Journal of Environmental Economics and Management, 51(1), 125.

Murphy, L., Benckendorff, P., Moscardo, G., \& Pearce, P. L. (2010). Tourist shopping villages: forms and functions. London: Routledge.

NBTC-Nipo Research (2007). Continuous Leisure Survey 2006-2007. Amsterdam: TNSNipo; The Hague: National Bureau of Congresses and Tourism.

Noonan, D., \& Krupka, D. (2010). Determinants of historic and cultural landmark designation: why we preseve what we preserve. Journal of Cultural Economics, $34(1), 1-26$.

Oppewal, H., Timmermans, H. J. P., \& Louviere, J.J. (1997). Modelling the effects of shopping centre size and store variety on consumer choice behaviour. Environment and Planning A, 29(6), 1073-1090.

Peacock, A. (1998). Does the past have a future? The political economy of heritage. London: Institute of Economic Affairs. 
RCE (2012). RCE Rijksmonumenten. Amersfoort: Rijksdienst voor het Cultureel Erfgoed.

Rizzo, I., \& Throsby, D. (2006). Cultural heritage: economic analysis and public policy. In V. A. Ginsburg, \& D. Throsby (eds.). Handbook of the Economics of Art and Culture (pp. 983-1016). Amsterdam: North Holland.

Shim, S., \& Gehrt, K.C. (1996). Hispanic and native American adolescents: an exploratory study of their approach to shopping. Journal of Retailing, 72(3), 307-324.

Statistics Netherlands (2012). Toerisme en recreatie in cijfers 2012. The Hague/Heerlen: Statistics Netherlands.

Statistics Netherlands (2013a). Begrippen: dagtocht. http://www.cbs.nl/nl$\mathrm{NL} / \mathrm{menu} / \mathrm{methoden} /$ begrippen/default.htm?ConceptID $=2938$. The Hague/Heerlen: Statistics Netherlands.

Statistics Netherlands (2013b). Statline: Regionale kerncijfers Nederland. http://statline.cbs.nl/StatWeb/selection/?DM=SLNL\&PA=70072NED\&VW=T. The Hague/Heerlen: Statistics Netherlands.

Teller, C., Reutterer, T., \& Schnedlitz, P. (2008). Hedonic and utilitarian shopper types in evolved and created retail agglomerations. The International Review of Retail, Distribution and Consumer Research, 18(3), 283-309.

Timothy, D. L., \& Boyd, S. W. (2006). Heritage tourism in the $21^{\text {st }}$ century: valued traditions and new perspectives. Journal of Heritage Tourism, 1(1), 1-16.

Train, K. E. (2009). Discrete choice methods with simulation. Cambridge, MA: Cambridge University Press.

Tuan, T. H., \& Navrud, S. (2008). Capturing the benefits of preserving cultural heritage. Journal of Cultural Heritage, 9(3), 326-337.

Yang, C.-H., Lin, H.-L., \& Han, C.-C. (2010). Analysis of international tourist arrivals in China: the role of World Heritage sites. Tourism Management, 31(6), 827-837. 


\section{Appendix A: Tourist region classification for the Netherlands}

Table A.1: Descriptive statistics of the tourist regions as classified by Statistics Netherlands

\begin{tabular}{|c|c|c|c|c|c|c|c|}
\hline & & Trips & $\begin{array}{l}\text { Munici- } \\
\text { palities }\end{array}$ & $\begin{array}{l}\text { Protected } \\
\text { cityscape } \\
\text { area size }\end{array}$ & $\begin{array}{l}\text { National } \\
\text { monuments }\end{array}$ & Museums & $\begin{array}{l}\text { Catering } \\
\text { facilities }\end{array}$ \\
\hline 1 & Wadden islands & 0.29 & 5 & 0.00 & 0.87 & 1.31 & 0.83 \\
\hline 2 & North Sea resorts & 4.23 & 20 & 7.67 & 5.29 & 6.81 & 5.78 \\
\hline 3 & IJsselmeer coast & 5.12 & 24 & 7.60 & 4.96 & 5.50 & 3.66 \\
\hline 4 & Delta area & 5.76 & 27 & 12.53 & 7.05 & 4.10 & 4.50 \\
\hline 5 & $\begin{array}{l}\text { Lakes in Groningen, Friesland } \\
\text { and Noordwest-Overijssel }\end{array}$ & 1.26 & 12 & 1.44 & 2.35 & 3.14 & 2.03 \\
\hline 6 & Holland-Utrecht Lakes & 0.52 & 8 & 0.83 & 2.17 & 0.61 & 1.27 \\
\hline 7 & Utrechtse Heuvelrug and 't Gooi & 3.45 & 14 & 6.01 & 3.18 & 2.62 & 3.31 \\
\hline 8 & Veluwe and Veluwerand & 5.54 & 18 & 2.32 & 3.34 & 6.63 & 4.65 \\
\hline 9 & Gelderland river area & 1.19 & 11 & 2.93 & 2.04 & 1.57 & 1.84 \\
\hline 10 & Achterhoek & 1.90 & 13 & 3.27 & 2.66 & 4.45 & 2.56 \\
\hline 11 & Twente, Salland and Vechtstreek & 6.28 & 22 & 2.03 & 5.22 & 6.89 & 5.24 \\
\hline 12 & $\begin{array}{l}\text { Sandy soils in Groningen, } \\
\text { Friesland and Drenthe }\end{array}$ & 3.82 & 18 & 2.04 & 3.17 & 5.50 & 3.52 \\
\hline 13 & West- and Middle-Brabant & 11.72 & 42 & 7.67 & 7.03 & 8.81 & 11.08 \\
\hline 14 & $\begin{array}{l}\text { East-Brabant, North- and Middle- } \\
\text { Limburg and Rijk van Nijmegen }\end{array}$ & 8.15 & 38 & 1.93 & 4.78 & 5.85 & 7.64 \\
\hline 15 & South-Limburg & 4.37 & 17 & 2.67 & 6.85 & 3.05 & 5.44 \\
\hline 16 & Amsterdam & 6.14 & 1 & 6.89 & 13.02 & 6.46 & 8.85 \\
\hline 17 & Rotterdam & 5.08 & 1 & 0.42 & 0.82 & 3.14 & 4.38 \\
\hline 18 & Den Haag & 3.30 & 1 & 12.87 & 2.02 & 2.79 & 4.14 \\
\hline 19 & Utrecht & 2.86 & 1 & 1.50 & 2.55 & 1.57 & 2.00 \\
\hline 20 & Rest of NL North & 4.41 & 30 & 9.13 & 8.32 & 8.03 & 4.40 \\
\hline 21 & Rest of NL West & 14.64 & 51 & 8.26 & 12.30 & 11.17 & 12.87 \\
\hline
\end{tabular}




\section{Appendix B: Graphical presentation of the alternative-specific constants}

This appendix contains graphs that show the value of the alternative-specific (municipalityspecific) constants across the Netherlands, which have been estimated in the nested logit models with three different heritage indicators. Those municipalities that receive a darker tone are often larger than those with a lighter tone.

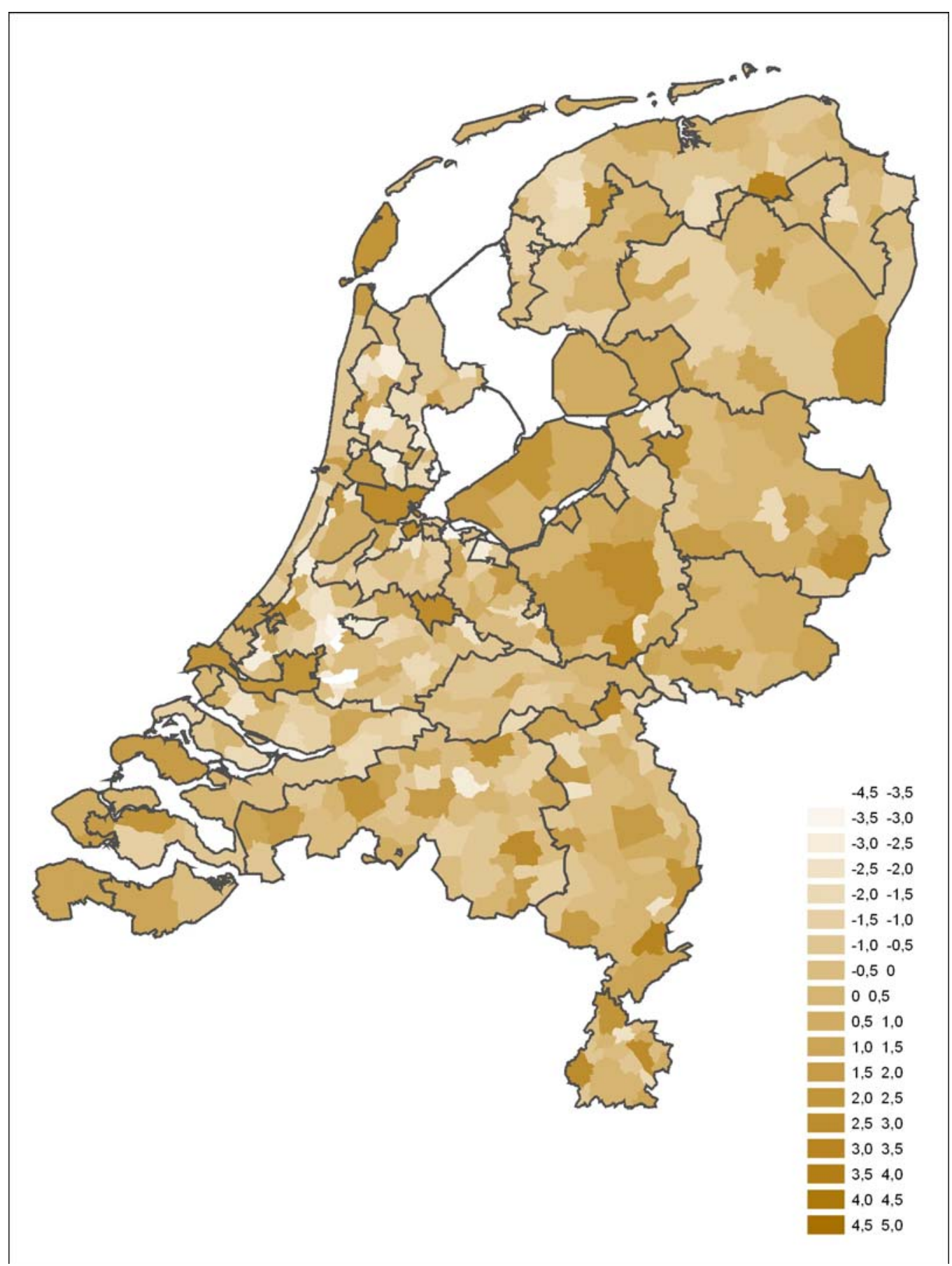

Figure B.1: Value of the alternative-specific constants with 'protected cityscape area size' as heritage indicator 


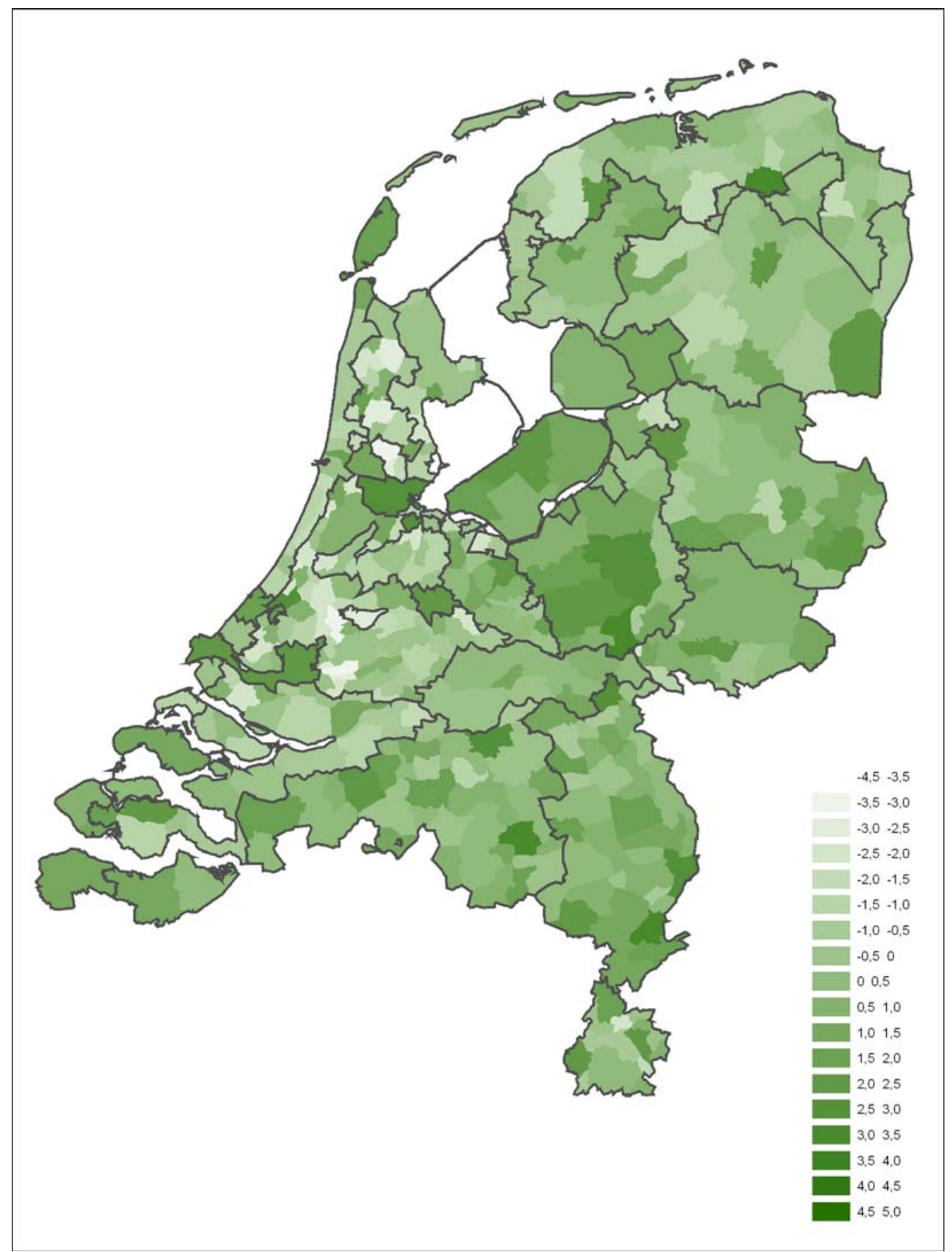

Figure B.2: Value of the alternative-specific constants with 'national monuments' as heritage indicator 


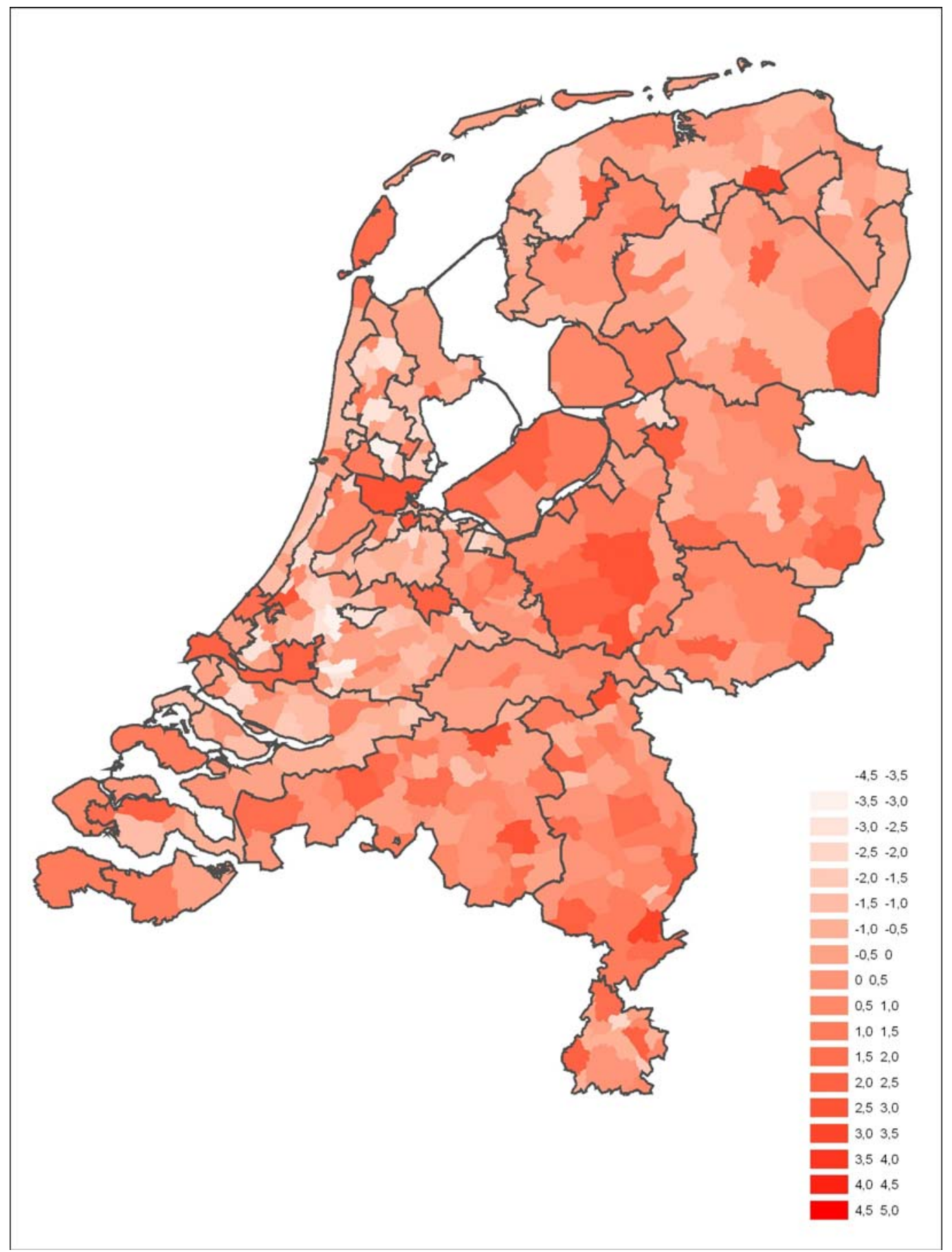

Figure B.3: Value of the alternative-specific constants with 'museums' as heritage indicator 


\section{Appendix C: Robustness analysis estimation results}

Table C.1: Estimation results of the nested-logit destination choice model, with “number of national monuments” as heritage indicator

\begin{tabular}{|c|c|c|c|c|c|c|c|c|}
\hline Main effect & Coefficient & S.E. & & & & & & \\
\hline Log of travel distance & $-2.361 * * *$ & 0.021 & & & & & & \\
\hline \multirow[t]{2}{*}{ Cross-effects } & \multicolumn{2}{|c|}{ Log of travel distance } & \multicolumn{2}{|c|}{ Number of catering facilities } & \multicolumn{2}{|c|}{ Number of national monuments } & \multicolumn{2}{|c|}{ Catering X National monuments } \\
\hline & Coefficient & S.E. & Coefficient & S.E. & Coefficient & S.E. & Coefficient & S.E. \\
\hline Single man & -0.055 & 0.060 & 0.030 & 0.019 & $-0.074 * * *$ & 0.024 & $0.014 * *$ & 0.005 \\
\hline No children & -0.085 & 0.052 & -0.002 & 0.016 & $-0.043 * *$ & 0.019 & $0.009 * *$ & 0.004 \\
\hline Child(ren) aged below 12 & $-0.269 * * *$ & 0.060 & 0.009 & 0.018 & $-0.092 * * *$ & 0.023 & $0.017 * * *$ & 0.005 \\
\hline Child(ren) aged 12 to 17 & $-0.263 * * *$ & 0.050 & -0.000 & 0.016 & $-0.095 * * *$ & 0.019 & $0.021 * * *$ & 0.004 \\
\hline Age26-50 & 0.042 & 0.034 & $-0.028 * * *$ & 0.009 & $0.029 * *$ & 0.013 & -0.003 & 0.003 \\
\hline Age51-99 & -0.019 & 0.039 & $-0.041 * * *$ & 0.010 & -0.030 & 0.016 & $0.011 * * *$ & 0.003 \\
\hline Non-native Dutch & $0.095 * *$ & 0.038 & 0.018 & 0.010 & -0.001 & 0.015 & -0.002 & 0.003 \\
\hline Household income & $0.012 * * *$ & 0.004 & 0.001 & 0.001 & 0.001 & 0.002 & -0.000 & 0.000 \\
\hline Weather & -0.028 & 0.018 & $0.009 * *$ & 0.004 & -0.009 & 0.007 & 0.001 & 0.002 \\
\hline
\end{tabular}

All coefficients are based on the sample of 7830 trips and the 403 municipalities that were revealed as destination. For the sake of brevity, we have not included the 402

alternative-specific constants, these are presented graphically in Figure A2. The estimates of the $\lambda_{k}$ parameter are given in Appendix D.

The reference to the first four respondent characteristics is "Single woman", and the reference to the age categories is "Age16-25". The variable "Household income" has been added to the model divided by 1,000 .

** Coefficient is statistically significant at the 0.05 level (2-tailed).

*** Coefficient is statistically significant at the 0.01 level (2-tailed).

The adjusted McFadden's pseudo $\mathrm{R}^{2}$ is 0.016 . The log-likelihood equals -15836.990 
Table C.2: Estimation results of the linear regression models, with "Number of national monuments" as heritage indicator

\begin{tabular}{|c|c|c|c|c|}
\hline & \multicolumn{2}{|c|}{$\begin{array}{c}\text { Ordinary least } \\
\text { squares regression }\end{array}$} & \multicolumn{2}{|c|}{$\begin{array}{c}\text { Instrumental } \\
\text { variables (2SLS) } \\
\text { regression } \\
\end{array}$} \\
\hline & Coefficient & S.E. & Coefficient & S.E. \\
\hline Catering facilities $(C A T)$ & $0.795 * * *$ & 0.053 & $1.030 * * *$ & 0.079 \\
\hline Number of national monuments $(\mathrm{CH})$ & $0.186 * * *$ & 0.043 & $0.446 * * *$ & 0.082 \\
\hline Catering facilities X Number of national monuments $(C H C A T)$ & $-0.055 * * *$ & 0.011 & $-0.150 * * *$ & 0.023 \\
\hline (Constant) & $-0.515 * * *$ & 0.159 & $-0.833 * * *$ & 0.190 \\
\hline \multicolumn{5}{|l|}{ Tourist region dummies: } \\
\hline TR Wadden islands & $1.102 * *$ & 0.487 & 0.944 & 0.512 \\
\hline TR North Sea resorts & -0.376 & 0.223 & $-0.532 * *$ & 0.246 \\
\hline TR IJsselmeer coast & 0.316 & 0.212 & 0.237 & 0.231 \\
\hline TR Delta area & 0.095 & 0.202 & 0.068 & 0.220 \\
\hline TR Lakes in Groningen, Friesland and Noordwest-Overijssel & $0.568 * *$ & 0.269 & 0.492 & 0.293 \\
\hline TR Holland-Utrecht Lakes & $-1.092 * * *$ & 0.273 & $-1.052 * * *$ & 0.298 \\
\hline TR Utrechtse Heuvelrug and 't Gooi & 0.426 & 0.236 & 0.357 & 0.258 \\
\hline TR Veluwe and Veluwerand & $0.889 * * *$ & 0.230 & $0.837 * * *$ & 0.253 \\
\hline TR Gelderlands river area & $0.632 * * *$ & 0.259 & $0.598 * *$ & 0.283 \\
\hline TR Achterhoek & $0.885 * * *$ & 0.248 & $0.812 * * *$ & 0.271 \\
\hline TR Twente, Salland and Vechtstreek & $0.857 * * *$ & 0.216 & $0.766 * * *$ & 0.237 \\
\hline TR Sandy soils in Groningen, Friesland and Drenthe & 0.258 & 0.236 & 0.175 & 0.259 \\
\hline TR West- and Middle-Brabant & $0.796 * * *$ & 0.187 & $0.815 * * *$ & 0.209 \\
\hline $\begin{array}{l}\text { TR East-Brabant, North- and Middle- Limburg and Rijk van } \\
\text { Nijmegen }\end{array}$ & $1.245 * * *$ & 0.193 & $1.263 * * *$ & 0.213 \\
\hline TR South-Limburg & 0.032 & 0.233 & -0.195 & 0.263 \\
\hline TR Amsterdam & $125.761 * * *$ & 31.40 & $389.641 * * *$ & 64.55 \\
\hline TR Rotterdam & $-8.556 * * *$ & 1.195 & $-5.175 * * *$ & 1.653 \\
\hline TR Den Haag & -2.633 & 1.966 & $11.368 * * *$ & 3.687 \\
\hline TR Utrecht & -0.828 & 0.828 & $8.141 * * *$ & 1.962 \\
\hline TR Rest of NL West & $-0.393 * *$ & 0.175 & -0.334 & 0.192 \\
\hline TR Rest of NL North & - & - & - & - \\
\hline Adjusted $\mathrm{R}^{2}$ & 0.638 & & 0.570 & \\
\hline Cragg-Donald Wald F-statistic & - & & 48.975 & \\
\hline \multicolumn{5}{|c|}{$\begin{array}{l}\text { All coefficients are based on the sample of } 7830 \text { trips and the } 403 \text { municipalities that were revealed as } \\
\text { destination. The first-stage estimation results of the instrumental variables regression are in Appendix E, } \\
\text { Table E.2. } \\
\text { ** The coefficient is statistically significant at the } 0.05 \text { level (2-tailed). } \\
\text { *** The coefficient is statistically significant at the } 0.01 \text { level (2-tailed). }\end{array}$} \\
\hline
\end{tabular}


Table C.3: Estimation results of the nested-logit destination choice model, with "number of museums" as heritage indicator

\begin{tabular}{|c|c|c|c|c|c|c|c|c|}
\hline Main effect & Coefficient & S.E. & & & & & & \\
\hline Log of travel distance & $-2.361 * * *$ & 0.021 & & & & & & \\
\hline \multirow[t]{2}{*}{ Cross-effects } & \multicolumn{2}{|c|}{ Log of travel distance } & \multicolumn{2}{|c|}{ Number of catering facilities } & \multicolumn{2}{|c|}{ Number of museums } & \multicolumn{2}{|c|}{ Catering X Museums } \\
\hline & Coefficient & S.E. & Coefficient & S.E. & Coefficient & S.E. & Coefficient & S.E. \\
\hline Single man & -0.051 & 0.060 & 0.024 & 0.052 & -0.020 & 0.029 & 0.002 & 0.004 \\
\hline No children & -0.078 & 0.052 & 0.016 & 0.044 & -0.031 & 0.025 & 0.004 & 0.003 \\
\hline Child(ren) aged below 12 & $-0.265 * * *$ & 0.060 & 0.060 & 0.052 & $-0.059 * *$ & 0.028 & 0.003 & 0.004 \\
\hline Child(ren) aged 12 to 17 & $-0.255 * * *$ & 0.050 & 0.023 & 0.045 & $-0.052 * *$ & 0.025 & $0.008 * * *$ & 0.003 \\
\hline Age26-50 & 0.047 & 0.034 & -0.000 & 0.028 & -0.015 & 0.015 & 0.003 & 0.002 \\
\hline Age 51-99 & -0.015 & 0.039 & -0.015 & 0.033 & $-0.039 * *$ & 0.019 & $0.010 * * *$ & 0.002 \\
\hline Non-native Dutch & $0.098 * * *$ & 0.038 & $0.063 * *$ & 0.032 & -0.024 & 0.018 & -0.002 & 0.002 \\
\hline Household income & $0.012 * * *$ & 0.004 & 0.006 & 0.004 & -0.002 & 0.002 & -0.000 & 0.000 \\
\hline Weather & -0.028 & 0.018 & 0.015 & 0.015 & -0.004 & 0.008 & -0.001 & 0.001 \\
\hline
\end{tabular}

All coefficients are based on the sample of 7830 trips and the 403 municipalities that were revealed as destination. For the sake of brevity, we have not included the 402 alternative-specific constants, these are presented graphically in Figure A2. The estimates of the $\lambda_{k}$ parameter are given in Appendix D.

The reference to the first four respondent characteristics is "Single woman", and the reference to the age categories is "Age16-25". The variable "Household income" has been added to the model divided by 1,000 .

** Coefficient is statistically significant at the 0.05 level (2-tailed).

$* * *$ Coefficient is statistically significant at the 0.01 level (2-tailed).

The adjusted McFadden's pseudo $\mathrm{R}^{2}$ is 0.015 . The log-likelihood equals -15848.231. 
Table C.4: Estimation results of the linear regression models, with "Number of museums" as heritage indicator

\begin{tabular}{|c|c|c|c|c|}
\hline & \multicolumn{2}{|c|}{$\begin{array}{l}\text { Ordinary least } \\
\text { squares regression }\end{array}$} & \multicolumn{2}{|c|}{$\begin{array}{c}\text { Instrumental } \\
\text { variables (2SLS) } \\
\text { regression }\end{array}$} \\
\hline & Coefficient & S.E. & Coefficient & S.E. \\
\hline Catering facilities $(C A T)$ & $1.151 * * *$ & 0.080 & $1.281 * * *$ & 0.137 \\
\hline Number of museums $(\mathrm{CH})$ & $0.130 * * *$ & 0.025 & $0.264 * * *$ & 0.055 \\
\hline Catering facilities $\mathrm{X}$ Number of museums ( $C H C A T$ ) & $-0.074 * * *$ & 0.010 & $-0.115 * * *$ & 0.017 \\
\hline (Constant) & $-0.722 * * *$ & 0.159 & $-1.064 * * *$ & 0.198 \\
\hline \multicolumn{5}{|l|}{ Tourist region dummies: } \\
\hline TR Wadden islands & $0.922 * *$ & 0.451 & 0.790 & 0.470 \\
\hline TR North Sea resorts & $-0.560 * * *$ & 0.216 & $-0.672 * * *$ & 0.229 \\
\hline TR IJsselmeer coast & 0.282 & 0.204 & 0.274 & 0.213 \\
\hline TR Delta area & 0.117 & 0.196 & 0.206 & 0.210 \\
\hline TR Lakes in Groningen, Friesland and Noordwest-Overijssel & 0.494 & 0.258 & 0.441 & 0.270 \\
\hline TR Holland-Utrecht Lakes & $-1.007 * * *$ & 0.264 & $-0.840 * * *$ & 0.283 \\
\hline TR Utrechtse Heuvelrug and 't Gooi & 0.418 & 0.227 & $0.481 * *$ & 0.242 \\
\hline TR Veluwe and Veluwerand & $0.952 * * *$ & 0.219 & $0.963 * * *$ & 0.229 \\
\hline TR Gelderlands river area & $0.644 * * *$ & 0.250 & $0.728 * * *$ & 0.265 \\
\hline TR Achterhoek & $0.712 * * *$ & 0.239 & $0.586 * *$ & 0.251 \\
\hline TR Twente, Salland and Vechtstreek & $0.667 * * *$ & 0.209 & $0.566 * *$ & 0.220 \\
\hline TR Sandy soils in Groningen, Friesland and Drenthe & 0.054 & 0.227 & -0.059 & 0.239 \\
\hline TR West- and Middle-Brabant & $0.718 * * *$ & 0.181 & $0.800 * * *$ & 0.198 \\
\hline $\begin{array}{l}\text { TR East-Brabant, North- and Middle- Limburg and Rijk van } \\
\text { Nijmegen }\end{array}$ & $1.180 * * *$ & 0.185 & $1.271 * * *$ & 0.204 \\
\hline TR South-Limburg & -0.038 & 0.228 & 0.106 & 0.255 \\
\hline TR Amsterdam & $174.639 * * *$ & 26.44 & $281.782 * * *$ & 44.61 \\
\hline TR Rotterdam & $30.216 * * *$ & 5.540 & $52.500 * * *$ & 9.277 \\
\hline TR Den Haag & $22.523 * * *$ & 4.523 & $40.763 * * *$ & 7.551 \\
\hline TR Utrecht & $3.136 * * *$ & 1.121 & $6.582 * * *$ & 1.620 \\
\hline TR Rest of NL West & $-0.378 * *$ & 0.168 & -0.268 & 0.182 \\
\hline TR Rest of NL North & - & - & - & - \\
\hline Adjusted $\mathrm{R}^{2}$ & 0.666 & & 0.640 & \\
\hline Cragg-Donald Wald F-statistic & - & & 27.747 & \\
\hline \multicolumn{5}{|c|}{$\begin{array}{l}\text { All coefficients are based on the sample of } 7830 \text { trips and the } 403 \text { municipalities that were revealed as } \\
\text { destination. The first-stage estimation results of the instrumental variables regression are in Appendix E, } \\
\text { Table E.3. } \\
\text { ** The coefficient is statistically significant at the } 0.05 \text { level (2-tailed). } \\
* * * \text { The coefficient is statistically significant at the } 0.01 \text { level (2-tailed). }\end{array}$} \\
\hline
\end{tabular}




\section{Appendix D: Scaling parameters for the tourist region nests}

Table D. 1 shows the scaling parameters $\lambda_{k}$ for each tourist region. The scaling parameter is set to a value of 1 for tourist regions 1,2 and 6 . The low number of visits to these tourist regions is perhaps responsible for the impossibility to estimate a parameter in the utility-consistent range of 0 and 1 . As the tourist regions of the 4 largest agglomerations consist of only one municipality each, the scaling parameter is also set to the value of 1 for these tourist regions. Interpreting the estimated models in terms of utility maximization would otherwise be problematic.

Table D.1: Scaling parameters for the tourist region nests, with different heritage indicators

\begin{tabular}{|c|c|c|c|c|c|c|c|}
\hline & & \multicolumn{2}{|c|}{$\begin{array}{l}\text { Protected cityscape } \\
\text { area size }\end{array}$} & \multicolumn{2}{|c|}{$\begin{array}{c}\text { Number of national } \\
\text { monuments }\end{array}$} & \multicolumn{2}{|c|}{ Number of museums } \\
\hline \multicolumn{2}{|c|}{ Tourist region } & Coefficient & S.E. & Coefficient & S.E. & Coefficient & S.E. \\
\hline & Wadden islands & 1 & - & 1 & - & 1 & - \\
\hline 2 & North Sea resorts & 1 & - & 1 & - & 1 & - \\
\hline 3 & IJsselmeer coast & $0.834 * * *$ & 0.047 & $0.834 * * *$ & 0.047 & $0.834 * * *$ & 0.047 \\
\hline 4 & Delta area & $0.850 * * *$ & 0.038 & $0.848 * * *$ & 0.038 & $0.855 * * *$ & 0.038 \\
\hline 5 & $\begin{array}{l}\text { Lakes in Groningen, Friesland and } \\
\text { Noordwest-Overijssel }\end{array}$ & $0.670 * * *$ & 0.065 & $0.670 * * *$ & 0.065 & $0.667 * * *$ & 0.066 \\
\hline 6 & Holland-Utrecht Lakes & 1 & - & 1 & - & 1 & - \\
\hline 7 & Utrechtse Heuvelrug and 't Gooi & $0.688 * * *$ & 0.046 & $0.693 * * *$ & 0.046 & $0.693 * * *$ & 0.046 \\
\hline 8 & Veluwe and Veluwerand & $0.671 * * *$ & 0.034 & $0.672 * * *$ & 0.034 & $0.672 * * *$ & 0.034 \\
\hline 9 & Gelderland river area & $0.594 * * *$ & 0.057 & $0.594 * * *$ & 0.057 & $0.592 * * *$ & 0.057 \\
\hline 10 & Achterhoek & $0.780 * * *$ & 0.062 & $0.779 * * *$ & 0.062 & $0.777 * * *$ & 0.062 \\
\hline 11 & Twente, Salland and Vechtstreek & $0.802 * * *$ & 0.031 & $0.802 * * *$ & 0.031 & $0.804 * * *$ & 0.030 \\
\hline 12 & $\begin{array}{l}\text { Sandy soils in Groningen, Friesland and } \\
\text { Drenthe }\end{array}$ & $0.926 *$ & 0.060 & $0.923 *$ & 0.060 & $0.923 *$ & 0.060 \\
\hline 13 & West- and Middle-Brabant & $0.721 * * *$ & 0.020 & $0.722 * * *$ & 0.020 & $0.723 * * *$ & 0.020 \\
\hline 14 & $\begin{array}{l}\text { East-Brabant, North- and Middle- } \\
\text { Limburg and Rijk van Nijmegen }\end{array}$ & $0.720 * * *$ & 0.025 & $0.720 * * *$ & 0.025 & $0.719 * * *$ & 0.025 \\
\hline 15 & South-Limburg & 1 & - & 1 & - & 1 & - \\
\hline 16 & Amsterdam & 1 & - & 1 & - & 1 & - \\
\hline 17 & Rotterdam & 1 & - & 1 & - & 1 & - \\
\hline 18 & Den Haag & 1 & - & 1 & - & 1 & - \\
\hline 19 & Utrecht & 1 & - & 1 & - & 1 & - \\
\hline 20 & Rest of NL North & $0.928 * * *$ & 0.023 & $0.931 * * *$ & 0.023 & $0.929 * * *$ & 0.023 \\
\hline 21 & Rest of NL West & $0.930 *$ & 0.058 & $0.931 *$ & 0.058 & $0.919 *$ & 0.057 \\
\hline
\end{tabular}




\section{Appendix E: First-stage instrumental variables regression estimation results}

This appendix presents the first-stage instrumental variables regression estimation results for each of the specifications. For the sake of brevity we do not report the coefficients for the tourist region dummies, which are available at request with the authors.

Table E.1: First-stage instrumental variables regression estimation results with "Protected cityscape area size" as heritage indicator

\begin{tabular}{l|lll}
\hline & $\begin{array}{l}\text { Number of } \\
\text { catering facilities }\end{array}$ & $\begin{array}{l}\text { Protected city- } \\
\text { scape area size }\end{array}$ & $\begin{array}{l}\text { Catering X } \\
\text { Cityscape }\end{array}$ \\
\hline Population 2007 & $0.205^{* * *}$ & -0.546 & $-0.091 * * *$ \\
& $(0.008)$ & $(1.182)$ & $(0.033)$ \\
Population 1830 & $0.209 * * *$ & $54.584 * * *$ & -0.297 \\
Population 2007 X Population 1830 & $(0.072)$ & $(10.811)$ & $(0.299)$ \\
& $3.718 * * *$ & 177.957 & $30.050 * * *$ \\
(Constant) & $(0.665)$ & $(99.228)$ & $(2.741)$ \\
& -0.001 & $-0.259 * *$ & 0.002 \\
Adjusted $\mathrm{R}^{2}$ & $(0.001)$ & $(0.114)$ & $(0.003)$ \\
F-test & 0.987 & 0.770 & 0.996 \\
\hline
\end{tabular}

The table lists coefficients, with the standard errors in brackets.

** The coefficient is statistically significant at the 0.05 level (2-tailed).

*** The coefficient is statistically significant at the 0.01 level (2-tailed).

Table E.2: First-stage instrumental variables regression estimation results with "Number of national monuments" as heritage indicator

\begin{tabular}{l|lll}
\hline & $\begin{array}{l}\text { Number of } \\
\text { catering facilities }\end{array}$ & $\begin{array}{l}\text { Number of national } \\
\text { monuments }\end{array}$ & $\begin{array}{l}\text { Catering X National } \\
\text { monuments }\end{array}$ \\
\hline Population 2007 & $0.021 * * *$ & $-0.006 * *$ & $-0.033^{* * *}$ \\
& $(0.001)$ & $(0.003)$ & $(0.011)$ \\
Population 1830 & $0.021 * * *$ & $0.296^{* * *}$ & $0.316^{* * *}$ \\
& $(0.007)$ & $(0.025)$ & $(0.101)$ \\
Population 2007 X Population 1830 & $0.000 * * *$ & 0.000 & $0.009 * * *$ \\
& $(0.000)$ & $(0.000)$ & $(0.001)$ \\
(Constant) & -0.095 & $-0.666^{* *}$ & $-2.413 * *$ \\
& $(0.078)$ & $(0.259)$ & $(1.068)$ \\
\hline Adjusted $\mathrm{R}^{2}$ & 0.987 & 0.941 & 0.999 \\
F-test & 1348.72 & 276.53 & 24028.05 \\
\hline The table lists coefficients, with the standard errors in brackets. \\
$* *$ The coefficient is significant at the 0.05 level (2-tailed). \\
*** The coefficient is significant at the 0.01 level (2-tailed). \\
\hline
\end{tabular}


Table E.3: First-stage instrumental variables regression estimation results with "Number of museums" as heritage indicator

\begin{tabular}{l|lll}
\hline & $\begin{array}{l}\text { Number of } \\
\text { catering facilities }\end{array}$ & $\begin{array}{l}\text { Number of } \\
\text { museums }\end{array}$ & $\begin{array}{l}\text { Catering X } \\
\text { Museums }\end{array}$ \\
\hline Population 2007 & $0.021 * * *$ & $0.020 * * *$ & $7.114 * * *$ \\
& $(0.001)$ & $(0.004)$ & $(1.205)$ \\
Population 1830 & $0.021 * * *$ & $0.314 * * *$ & 3.138 \\
& $(0.001)$ & $(0.041)$ & $(11.029)$ \\
Population 2007 X Population 1830 & $0.000 * * *$ & -0.000 & $1.089 * * *$ \\
& $(0.000)$ & $(0.000)$ & $(0.101)$ \\
(Constant) & -0.095 & 0.203 & $-232.785 * *$ \\
& $(0.077)$ & $(0.429)$ & 0.999 \\
\hline Adjusted R ${ }^{2}$ & 0.987 & 0.886 & 21800.72 \\
F-test & 1349.20 & 136.32 & \\
\hline The table lists coefficients, with the standard errors in brackets. \\
** The coefficient is significant at the 0.05 level (2-tailed). \\
$* * *$ The coefficient is significant at the 0.01 level (2-tailed). \\
\hline
\end{tabular}

